\title{
AZ ÖNSZABÁLYOZÓ TANULÁS FEJLETTSÉGÉNEK ÖSSZEFÜGGÉSEI A TANULÁSI EREDMÉNYESSÉGGEL ÉS AZ IKT-HASZNÁLAT GYAKORISÁGÁVAL
}

\author{
DÁVID MÁRIA - TASKÓ TÜNDE - HÉJJA-NAGY KATALIN - \\ MESTER DOLLI - DORNER LÁSZLÓ - \\ ESTEFÁNNÉ VARGA MAGDOLNA \\ Eszterházy Károly Főiskola Pszichológia Tanszék \\ e-mail: davidm@ektf.hu; taskot@ektf.hu; hejjank@ektf.hu; dollim@ektf.hu; \\ dorner@ektf.hu; estefan@ektf.hu
}

Beérkezett: 2015. november 20. - Elfogadva: 2015. december 15.

Háttér és célok: Új típusú pedagógiai problémákat vet fel az infokommunikációs technológiák elterjedésével általánossá váló önálló információkeresés és feldolgozás. A tanuló oldaláról feltételezi az önálló tanulást, az információk hatékony feldolgozását, megértését. A tanár oldaláról pedig a tudásátadó szerep helyett a tanulásirányító szerep hangsúlyosabbá válását (Molnár, 2011). Az élethosszig tartó tanulás iránti társadalmi igény az önszabályozó tanulási készség fejlödése nélkül nem teljesülhet. Ugyanakkor a tanulók önreflektív és önszabályozó képessége a tanulás, tanitás folyamatában még kiaknázatlan (Molnár, 2002). A cikkben bemutatjuk egy keresztmetszeti összehasonlító kutatás eredményeit, melynek célja a tanulás eredményessége, az infokommunikációs eszközök használatának sajátosságai és az önszabályozó tanulás fejlettsége közötti összefüggések feltárása.

Módszer: 2015 novemberében lezárult keresztmetszeti kutatásunkban a 10-14-18 és 22 éves korosztályban összesen 1257 fös mintán vizsgáltuk az önszabályozó tanulás fejlödését. Vizsgálatunkban a kutatócsoport által kifejlesztett önszabályozó tanulás kérdöivet használtuk, mely 59 itemet tartalmaz, valamint összegyüjtöttük a tanulmányi eredményeket és a matematika és szö̃egértés kompetenciamérések adatait.

Eredmények: A korcsoportok között szignifikáns különbségek vannak az önszabályozó tanulás fejlettsége szempontjából. Az életkor elörehaladtával az eredmények javulnak, de a kérdöív faktoraiban szinte minden korosztályban alacsony átlagértékeket kaptunk. Az önszabályozó tanulás fejlettségi szintje mérsékelt, de szignifikáns pozitív korrelációt mutat mind a tanulmányi eredményekkel, mind a kompetenciamérés eredményeivel Az infokommunikációs eszközök átlagnál gyakoribb használata az önszabályozó tanulás alacsonyabb szintjével jár együtt. 
Következtetések: Az adatok azt mutatják, hogy az önszabályozó tanulás fejlesztésére minden korosztályban szükség van. Törekedni kell arra, hogy az infokommunikációs eszközök használata a tanulóknál ne haladja meg az átlagos mértéket.

Kulcsszavak: önszabályozó tanulás, tanulási eredményesség, IKT-használat

A technikai fejlődés felgyorsulása jelentős változásokat hozott a XXI. század kezdetére. Az internet megjelenése megkönnyítette az információhoz való hozzáférést, megváltoztatta a mindennapi élet tevékenységformáit, hatása a tanulási tevékenységek átrendeződésében is megfigyelhető. A felgyorsult fejlődés az új és még újabb felfedezések révén minden szakterületen szükségessé teszi az ismeretek megújítását, kiterjesztve a felnőtt korra is a formális a tanulási szakaszokat. Az egész életen át tartó tanulás a mai ember életének realitása, a tudás alapú társadalom záloga. A Lifelong Learning fogalma az iskolai előkészítéstől a nyugdíj utáni korig terjedően magában foglal minden formális, nem formális és informális tanulást. Minden olyan tanulási tevékenység beleértendő, amely tudás, készségek és képességek fejlesztése céljából történik, személyes, állampolgári, társadalmi és/vagy foglalkoztatási szempontból (Making a European Area of Lifelong Learning a Reality. European Commission, 2001, 5). Különös jelentőséggel bír tehát, hogy a XXI. század embere legyen képes az önálló információszerzésre és annak feldolgozására, tanulását tudja tervezni és irányítani. Az egész életen át tartó tanulás szakpolitikájának keretstratégiája a 2014/2020 közötti időszakra így fogalmaz (2014, 9): „Az egész életen át tartó tanulás fókuszában a tanulásnak, a tanulási folyamat személyre szabásának, a tanulni akaró egyén szükségleteinek és képességeinek kell állnia.” Jelen cikkünkben ismertetett kutatásunkkal szeretnénk hozzájárulni az önszabályozó tanulás és a tanulási eredményesség közötti kapcsolat feltárásához, a tanulási tevékenység fejlesztéséhez.

\section{AZ ÖNSZABÁLYOZÓ TANULÁS FOGALMA ÉS JELLEGZETESSÉGEI}

Az önszabályozás a legáltalánosabb értelemben azt jelenti, hogy képesek vagyunk saját tevékenységeinket szabályozni, kontrollálni, azaz az én szabályozva van az én által (McDermott és Fox, 2010).

Az önszabályozó tanulás (self-regulated learning) kifejezés a nemzetközi szakirodalomban az 1980-as évek végén, 1990-es évek elején terjedt el, amelyet újabb fordításokban a „tanulás önszabályozása”, „önszabályozás a tanulási folyamatban”, „önszabályozott tanulás” kifejezésekkel fordítanak, elsősorban az önszabályozó képesség tanulásban kiaknázott szerepét kiemelve (Molnár, 2009).

Az önszabályozó tanulás feltételezi az önmegfigyelést, nyomon követést (monitorozást), a kontrollt és a szabályozást, mindezt a tanulás során kitűzött cél elérése érdekében (Molnár, 2002). A monitorozás a kognitív kontroll fontos eleme, és 
szorosan kapcsolódik az értékelő és döntéshozási folyamatokhoz, és tágabb értelemben az önszabályozott viselkedéshez (McDermott és Fox, 2010).

Az önszabályozó tanulás tehát egy komplex, interaktív, az akarat által vezérelt folyamat, amelyben szerepet játszanak a motiváció és a kognitív önszabályozó tevékenységek is (Csíkos, 2010).

A tanulás eredményessége nagymértékben függ attól, hogy a tanuló mennyire tud autonóm módon, aktívan bevonódni a tanulási folyamatba (Broadbent és Poon, 2015). Az online tanulási környezet további nehézségeket rejt magában. A tanári jelenlét hiánya ugyanis előnyei mellett buktatókat is tartogathat, ha a tanuló nincs felkészülve az önálló ismeretszerzésre. A tanulás nem annyira strukturált, a tanuló kevesebb segítséget, támogatást kap az anyag feldolgozásához, nagyobb szükség van rá, hogy saját tanulását önállóan, önmaga szervezze, mint a hagyományos tanulási környezetben (Faragó, 2015). A tanulási tér, idő és a tanulási folyamat menedzselése, nyomon követése, szabályozása online környezetben tehát az oktatótól egyértelműen a diákhoz kerül át (Artino és Jones, 2012). Megfelelő készségek hiányában sokszor nehézséget okoz a tanulóknak saját tanulási tervük elkészítése és tanulási módszereik, stratégiáik kiválasztása, az elérhető tananyag és információtartalom szelektálása. Tovább nehezíti a tanulást az elektronikus környezetben rejlő sok zavaró inger (Shih, Chen, Chang és Kao, 2010).

A különböző kutatási irányzatok, elméleti megközelítések az önszabályozó tanulás más és más elemeit és mechanizmusait hangsúlyozzák, ugyanakkor az önszabályozó tanuló jellemzőinek leírásában sok hasonlóságot mutatnak (Taskó, 2011). Az önszabályozó tanulók aktívak, a tanulást maguk kezdeményezik, képesek személyes céljaik megfogalmazására, önállóak és kitartanak feladataik végrehajtása mellett. Hatékony tanulási stratégiákat alkalmaznak, önreflektívek, a tanulásra vonatkozó metakognitív tevékenységet végeznek, saját képességeiket reálisan ismerik, és a következmények jelentőségét felmérik. Kialakult érdeklődéssel és a tanulással szemben pozitív attitűddel rendelkeznek.

Vermunt (1998) külső es belső szabályozást különböztet meg. A külső szabályozás esetében a tanuló a tanártól vagy a kijelölt tantárgyi tartalmaktól várja a szabályozást: ezek fogják meghatározni, hogy mi a tanulás célja, hogy mit és hogyan kell tanulni, és hogy eredményes volt-e a tanulás vagy sem. A belső szabályozás, azaz az önszabályozó tanulás során viszont a tanuló maga dönt a fenti kérdésekről: ő választja meg a célt, ő tervezi meg a folyamatot, ő keresi meg a tartalmakat, forrásokat, és ő határozza meg, hogy a tanulás eredményes volt-e vagy sem. A felsőoktatás hallgatóinak tanulását vizsgáló kutatások egy harmadik típust is leírnak, amikor teljes a bizonytalanság a tanulás szabályozásában. Nem értik a feladatot, nem tudják a követelményeket, vagy azt, hogy kihez fordulhatnak, ha elakadnak, vagyis a tanulás szabályozásának hiánya jellemzi őket.

A viselkedés önszabályozása, a személy önkontrolljának fejlettségi foka és az önszabályozó tanulási képességei összefüggenek egymással. A tanulási folyamat szabályozása ugyanakkor a viselkedés irányításának egy szűkebb dimenziója, ezen belül valósul meg a tanulás irányítása, és a metakognitív stratégiák alkalmazása. A legközvetlenebb viselkedésirányítási szint pedig a konkrét tananyag feldolgozása, és ehhez az illeszkedő kognitív stratégiák kiválasztása (Boekaerts, 1999). 
Az önszabályozó tanulás négy fő fázisban zajlik le (Pintrich, 2000): A célkitűzésen, tervezésen és aktiváláson túlmenően a feladat végrehajtását, e cselekvések monitorozását, kontrollálását, a figyelemmel kísért események szükség szerinti korrekcióját jelenti. Az utolsó fázisban pedig az elvégzett tevékenységre vonatkozó önreflexiók elemzését, visszacsatolását. A tanulók összevetik a teljesítményüket a célkitűzésben megfogalmazott elvárásokkal, önreflexiós bírálatot, értékelést fogalmaznak meg a saját teljesítményükről. Ezek az önreflexiók képezik az alapot a megfelelő következtetések levonásához, és ha szükséges, a szükséges változtatások megtervezéséhez.

\section{METAKOGNITÍV SZABÁLYOZÁS ÉS TANULT LELEMÉNYESSÉG}

A metakogníció fogalma eredetileg Flavell (1979) nevéhez köthető, aki a saját kognitív folyamatainkkal kapcsolatos tapasztalatokat és ismereteket értette ezen. Az önszabályozást a metakognitív stratégiák egyikének tekintette, és összefüggésbe hozta az alkalmas tanulási stratégiák megválasztásával.

A ma elfogadott definíciók értelmében a metakogníció olyan tudatos kognitív tevékenység, ami által tudomást szerezhetünk saját megismerési folyamatainkról, gondolkodásunkról, azokat képesek vagyunk tervezni, nyomon követni, ellenőrizni és szabályozni (Revákné Markóczi, Máth, Huszti és Pollner, 2013). A helyes tanulást a metakognitív irányítás jellemzi, és a tanulók ellenőrzésük alatt tartják a tevékenységeiket. Képesek előre tervezni a cselekedeteiket és előre számolni a következményekkel. A személyes korlátokra és kompenzációs lehetőségekre vonatkozó metakognitív tudatosság hiánya jelentősen hozzájárul a tanulási kudarcokhoz (Zimmerman, 2002).

A metakogníció és a tanulás összefügg, sőt mondhatjuk, hogy a sikeres tanulás elképzelhetetlen fejlett metakognitív stratégiák (például monitorozás, értékelő folyamatok stb.) alkalmazása nélkül. Fisher (2000) szerint a helyes gondolkodást és tanulást a metakognitív irányítás jellemzi. „Metakognitív tanulơ”-ról beszél, aki ismeri a gondolkodási folyamatot, ezen belül önmagát, a feladatot és a stratégiát, és irányítja a gondolkodási folyamatot, az önálló tanulást és a tanulás kiterjesztését.

Réthyné (2003) a metakogníció tanulásra gyakorolt hatását elemző kutatásokat összefoglalva kiemeli, hogy vannak ellentétes nézőpontok. Némelyek a metakognitív folyamatokat tartják dominánsnak és felelősnek a tanulási stratégiák kontrolljáért és szabályozásáért, mások úgy látják, hogy a tanulási stratégiák és a módszertani repertoár megszilárdítása vezet a metakognitív kompetencia, az önirányítás és önmeghatározás növekedéséhez. Úgy véli, hogy a tanulást csak akkor kezdi meg és folytatja önállóan a tanuló, ha annak következményeit, illetve céljait pozitívan értékeli, és ha megéli az önálló hatékonyság és felelősség érzését.

Csíkos (2004) szerint a tanulók saját tanulásukkal kapcsolatos tudása fontos szerepet játszik a tanulás hatékonyságában és eredményességében.

Schraw (2001) a metakogníció két nagy területét különíti el: a metakognitív tudást és metakognitív szabályozást. 
A metakognitív szabályozás három fő lépése a tervezés, a monitorozás-nyomon követés és az ellenőrzés-értékelés. (Fischer, 2000). A metakognitív szabályozás képessége meghatározó szerepet tölt be a problémamegoldás folyamatában és a tanulási folyamatban is. A tervezés, a nyomon követés és az értékelés képességének szintjétől nagymértékben függ az, hogy mennyire hatékony a problémamegoldás.

Snow és Jackson (1999) kiemeli az iskolai tanulás akarati tényezőit, a kitartással, a munkaerkölccsel, a tanulási szándékkal, a befektetett szellemi erőfeszítéssel és a tanulásra való odafigyeléssel kapcsolatos tulajdonságokat. Olyan szándéktényezők is ide sorolhatók, mint a választott célok felé vezető cselekvések kontrollja vagy szabályozása, a jövővel kapcsolatos attitűdök, a közeli és távlati célokkal kapcsolatos éntudatosság, valamint azok a különböző tanulási stílusok és stratégiák, amelyek befolyásolják a megismerő folyamatokat és az oktatás eredményességét.

A tanult leleményesség: Rosenbaum (1988) szerint a kontrollált viselkedést folyamatszabályozó kogníció kíséri, melynek két fajtája: a helyreállító (redresszív) és az átalakító, javító (reformatív) önkontroll. Az életmód-változtatást igénylő helyzetek a reformatív önkontrollfunkció életbeléptetését teszik szükségessé. Az átalakító önkontroll megkívánja a személy rugalmas viselkedését, azt, hogy a helyzetet kihívásként fogja fel, és aktívan törekedjen annak pozitív irányú megváltoztatására. Ez az önkontrollfunkció képezi a „tanult leleményesség” alapját, amelynek a maladaptív, káros viselkedés monitorozása, tudatosítása, problémamegoldó stratégiák alkalmazása, majd érzelemszabályozó és más önkontroll-stratégiák alkalmazása révén teszi lehetôvé a nem hatékony tanulási szokások felismerését és megváltoztatását.

\section{AZ ÖNREFLEXIÓ SZEREPE AZ ÖNSZABÁLYOZÓ TANULÁS FEJLESZTÉSÉBEN}

A reflexió olyan gondolkodási stratégia, amely biztosítja a tevékenységek folyamatos elemzését, ellenőrzését és ezen alapuló fejlesztését. A reflektálás során tehát tudatosan végiggondoljuk egy tevékenység eredményességét, annak okait, következményeit, és szükség esetén a változtatási lehetôségeket. Nemcsak reagálunk a történésekre, hanem befolyásoljuk is azokat. A reflexiónak két iránya lehet a szakmai tevékenységre (esetünkben a tanulásra) irányuló, illetve a személyre irányuló elemzés (Szivák, 2010).

A reflexió a gyakorlatban kétféleképpen nyilvánulhat meg: a tevékenység közben, amikor a tervezett tanulási folyamat éppen megvalósul, és a tevékenység után, amikor a megvalósult tanulási folyamatot elemezzük, értékeljük. Ennek eredményeként a következő szakaszra vagy a következő alkalomra szóló tervünkön módosíthatunk (Hunya, 2014).

A tanulásra vonatkozó kognitív reakciók és reflexiók magukban foglalják a tanulók bírálatait, értékeléseit és attribúcióit saját teljesítményükről az adott feladaton belül. Az önszabályozó tanulás utolsó fázisában, a tanulási tevékenység végén a tanulók visszacsatolás útján összevetik a teljesítményüket a célkitűzésben megfogalmazott, elvárt célállapottal. 
Bandura (1995) az önreflexivitás fázisában két folyamatot különböztet meg: az önbírálatot (ez az önértékelési folyamatokat is magába foglalja) és az önreagálást, amely függ a személy önbírálat-érzékenységétől és attól, hogy mennyire tud kritikus lenni saját magával szemben. Az önbírálatnak két kulcsfontosságú következménye lehet: az egyik önmegelégedés, a másik az „alkalmazkodó következtetés”. Ennek során az egyén megfogalmazza, hogy mire van még szükség a tanulási tevékenység folyamán, milyen erőkifejtéseket kell még tennie stb.

Ha sikeres ez a folyamat, a későbbiekben jobb önszabályozási stratégiákat használ a személy. A tanulásra vonatkoztatott önreflexió segít a tanuláshoz szükséges tulajdonságok, szokásrendszer, alkalmazott módszerek, tanulási technikák áttekintésében, az erősségek és a gátló tényezők felismerésében, és a szükséges változtatások megtervezésében.

\section{AZ ÖNSZABÁLYOZÓ TANULÁS MÉRÉSE}

Az önszabályozó tanulás mérésére az elmúlt évtizedekben két fő irányzat körvonalazódott a kutatási metodológiák terén (Kovács, 2013; D. Molnár, 2014). Az egyik a tanulási jellemzők mentén a személyiségvonások köré szerveződik, a másik pedig a kognitív fejlődés, a folyamat jelleg vizsgálatára irányul, azon belül a végrehajtó funkciók és az információfeldolgozó folyamatok/képességek számbavétele valósul meg bennük. Az első irányzat kutatásaiban a leggyakoribb eszközök a kérdőívek, valamint strukturált interjúk voltak, amelyben arra kérték a tanulókat, hogy idézzék fel, milyen stratégiákat használnak tanulás közben, milyen módon tervezik, irányítják, szabályozzák, majd értékelik saját tanulási tevékenységüket. Saját vizsgálatunk ebbe az első kutatási irányzatba sorolható.

A továbbiakban a teljesség igénye nélkül áttekintjük azokat a kutatási eredményeket, amelyek az önszabályozó tanulás fejlettsége és a tanulási eredményesség összefüggéseit vizsgálták.

Hazánkban az önszabályozó tanulás mérésére először Molnár Éva vállalkozott (2002). Kérdőíves vizsgálatában a tanulmányi átlag és a tanulási képesség között talált erős korrelációt $(r=0,54)$. Vizsgálatában a tanulmányi átlag a tanulási szokásokkal és motivációkkal egyaránt szorosabb összefüggést mutatott. Két korcsoportot 8. és 11. évfolyamokat összehasonlítva azt találta, hogy az életkor előrehaladtával az eredményekben csökkenő tendencia figyelhető meg, a 11. évfolyam gyengébb eredményt produkált az önszabályozó tanulási készségek több területén. Az életkor előrehaladtával megfigyelhető csökkenő tendenciát nemzetközi jelenségnek tartja, és úgy véli, ez azzal magyarázható, hogy az iskola elsősorban a „művi” tanulás színhelye, a természetes tanulás visszaszorul, a célkitűzések, a kivitelezés, az értékelés, a monitorozás és kontrollálás kívülre kerül, az iskola vállalja át ennek beteljesítését, nem engedve megfelelő teret a tanulók önálló, önszabályozó munkájának (Molnár, 2002).

Molnár Éva (2013) saját 2004-es kutatásaiban is pozitív összefüggéseket talált az iskolai eredményesség és az önszabályozott tanulás egyes komponensei között. 6. évfolyamos mintában a metakognitív stratégiák és az ismétlés közel azonos erős- 
ségben határozták meg a tanulmányi átlagot $(r=0,45 ; r=0,44)$. Azok a tanulók, akik tanulásuk során gyakran használnak tervező, nyomon követő, értékelő stratégiákat, többször ismételnek, jobban megszervezik a tanulásukat, és kitartóbbak, jobb tanulmányi átlagot érnek el. Akik halogatnak, azoknak gyengébb a tanulmányi átlaga.

Magunk 2008-ban hasonlítottuk össze az általunk kifejlesztett tanulásdiagnosztikai kérdőív ${ }^{1}$ faktorait a tanulmányi eredményekkel. Azt találtuk, hogy a kérdőívben mért faktorok (Tanulási képességek - figyelem, gondolkodás, emlékezet, szókincs; Tanulási technikák és stratégiák; A tanulás tervezése; Pozitív énkép; Önbizalom; Érdeklődés és motiváció) szignifikánsan magasabb értékeket mutatnak a jobb tanulmányi átlaggal rendelkező tanulóknál (Dávid, Estefánné Varga és HéjjaNagy, 2008).

A nyelvtanulási autonómia, az önszabályozó stratégiák és a motiváció kapcsolatát vizsgálva Csizér és Kormos (2012) a legerősebb kapcsolatot az önszabályozó tanulás és a motivált tanulási viselkedés között találta. Szerintük az önszabályozás leginkább a motivációval függ össze. Az autonóm tanulási viselkedés alacsonyabb az elvárhatónál. Ezeket az adatokat ők is a magyarországi osztálytermek tanárközpontú világával magyarázzák, ami az idegen nyelvi órákra is jellemző. Az összefüggés-vizsgálataik eredményei megerősítik a szakirodalmi állításokat, melyek szerint a motiváció, az önszabályozás és az autonómia egymást erősítő folyamatok.

Bacsa Éva (2012) kutatási eredményei is arra mutatnak rá, hogy az önszabályozott tanulás fejlettsége nem túl magas, de szignifikáns összefüggést mutat az iskolai teljesítménnyel. Szerinte az önszabályozott tanulás összetevői a tanulmányi eredményesség mintegy 20\%-át magyarázzák, s ezek közül három változó rendelkezik szignifikáns magyarázóerővel. A legnagyobb magyarázóerőt (7\%) a felszíni stratégiák adják, amely azt jelenti, hogy a tanulók között azok az eredményesebbek, akik az ismétlő, memorizáló, „magoló” tanulási stratégiákat használják. Ez az eredmény arra utal, hogy az iskola még mindig a mechanikus tanulási stratégiát erősíti meg, ahelyett, hogy a megértésre építő, mélyre hatoló tanulási stratégiák kialakítását preferálná. Jelentősebb magyarázóerőt képviseltek még Bacsa (2012) kutatásában a tanulás tervezésével (5\%) és nyomon követésével (4\%) kapcsolatos változók, valamint a metakognitív stratégiák is.

\section{A KUTATÁS CÉLJA ÉS HIPOTÉZISEI}

Jelen kutatásunk egy keresztmetszeti összehasonlító és feltáró kutatás, amely a 1022 éves korosztályban, 4 korcsoportra bontva vizsgálja a számítógép-használati sajátosságok mentén az önszabályozó tanulás fejlődésének jellegzetességeit, valamint a tanulás eredményessége, a munkamemória és az önszabályozó tanulás fejlettsége közötti összefüggéseket.

${ }^{1}$ A tanulásdiagnosztikai kérdőív az alábbi linken érhető el: http://tanulasfejlesztes.ektf.hu/ 
A kutatás céljai több területre terjednek ki. Fő cél: az önszabályozó tanulás és a munkamemória fejlődési jellegzetességeinek feltárása a különböző korcsoportokban. Jelen tanulmányunkban csak az önszabályozó tanulás fejlődési jellegzetességeire térünk ki. A munkamemória-eredményeket a kötet másik cikke tartalmazza.

További célként jelenik meg annak vizsgálata, hogy a tanulási eredményesség milyen összefüggésben áll az önszabályozó tanulás fejlettségi szintjével, valamint annak megállapítása, hogy az infokommunikációs technológiák (IKT) használati gyakorisága milyen összefüggésben áll az önszabályozó tanulás fejlettségével.

\section{Kutatási hipotézisek:}

- Feltételeztük, hogy korcsoportonként eltéréseket találunk a tanulás önirányításában és a tanulási technikák használatában. Az életkor előrehaladtával növekvő értékeket vártunk az önszabályozó tanulás mentén.

- Feltételeztük, hogy az önszabályozó tanulás kérdőívének faktoraiban azon tanulók eredményei lesznek jobbak, akik magasabb tanulmányi átlaggal és magasabb kompetenciamérési eredményekkel rendelkeznek.

- Feltételeztük továbbá, hogy az infokommunikációs technológiák (IKT) használati gyakoriságával is összefüggésbe hozható az önszabályozó tanulás fejlettsége. Feltételeztük, hogy az IKT-eszközök átlagos mértékű használata mellett a tanulás önszabályozása is magasabb szintű lesz.

A hipotézisek vizsgálatára irányuló kutatásunk adatfelvételére 2015. augusztus 25. és szeptember 30. között került sor.

\section{VIZSGÁLATI MÓDSZEREK}

Hipotéziseink igazolására két módszert alkalmaztunk. Egy, a kutatócsoport által kifejlesztett online kérdőívet, melynek segítségével a számítógép-használati szokásokat és az önszabályozó tanulás fejlettségét vizsgáltuk, valamint egy dokumentumelemzési szempontsort az iskolai teljesítmények mérése az adott korcsoportokban. A matematikai és szövegértési kompetenciamérések adatait elemeztük, illetve az iskolai érdemjegyeket, tanulmányi átlagokat.

A hipotézisek vizsgálatára szerkesztett kérdốiviük három fő szerkezeti egységből állt (a teljes kérdőív megtekinthető e kutatás záró tanulmányában - Dávid és mtsai, 2015).

- Az első szerkezeti egység (7 item) a tanulók alapadatait és szociális státusát vizsgálja (életkor, nem, szülők iskolai végzettsége, lakhely típusa).

- A második szerkezeti egység (8 item) a számítógép-használati szokásokra vonatkozóan tesz fel kérdéseket.

- A harmadik szerkezeti egység pedig (59 item) az önszabályozó tanulás jellemzőire kérdez rá, négy fő területen, főként 5 fokú Likert-típusú skálán, és zárt kérdésekkel. 
Válaszlehetöségek:

\begin{tabular}{|c|c|}
\hline & Egyáltalán nem jellemző rám \\
\hline 2. & \\
\hline 3. & Csak kismértékben jellemző rám \\
\hline 4. & Jellemző is meg nem is \\
\hline 5. & Jellemző rám \\
\hline
\end{tabular}

Teljesen jellemző rám

\section{Instrukció}

Az állítások melletti számok közül jelöld be azt, amelyik szerinted a legjobban kifejezi, hogy az állítás mennyire jellemez téged. Minél nagyobb számot jelölsz meg, annál inkább jellemzőnek tartod magadra nézve az adott állítást.

1. táblázat. Példák az online kérdőív ${ }^{2}$ itemeire faktoronként

\begin{tabular}{|c|c|c|c|c|c|c|}
\hline $\begin{array}{l}\text { A kérdőív fö } \\
\text { faktorai }\end{array}$ & Példák a z itemekre & 1. & 2. & 3. & 4. & 5. \\
\hline \multirow{3}{*}{ 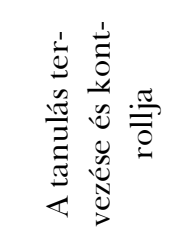 } & $\begin{array}{l}\text { 1. A napi teendőimet előre megterve- } \\
\text { zem. }\end{array}$ & $\square$ & $\square$ & $\square$ & $\square$ & $\square$ \\
\hline & $\begin{array}{l}\text { 2. Megtervezem, mennyi időt fogok az } \\
\text { egyes tárgyak tanulásával eltölteni. }\end{array}$ & $\square$ & $\square$ & $\square$ & $\square$ & $\square$ \\
\hline & $\begin{array}{l}\text { 3. Megtervezem a megtanulandó tan- } \\
\text { anyagok sorrendjét. }\end{array}$ & $\square$ & $\square$ & $\square$ & $\square$ & $\square$ \\
\hline \multirow{3}{*}{ 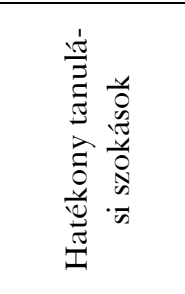 } & $\begin{array}{l}\text { 16. Mindig pontosan tudom, hogy mi a } \\
\text { házi feladat, mit kell megtanulni. }\end{array}$ & $\square$ & $\square$ & $\square$ & $\square$ & $\square$ \\
\hline & $\begin{array}{l}\text { 18. Tudom, hogy milyen sorrendben } \\
\text { tanulom meg a különböző tantár- } \\
\text { gyakat. }\end{array}$ & $\square$ & $\square$ & $\square$ & $\square$ & $\square$ \\
\hline & $\begin{array}{l}\text { 21. Rendet tartok magam körül tanulás } \\
\text { közben. }\end{array}$ & $\square$ & $\square$ & $\square$ & $\square$ & $\square$ \\
\hline
\end{tabular}

${ }^{2}$ A kérdőív online változatban készült el, és az adatfelvétel is online történt. A kutatócsoport által szerkesztett online kérdőív a kutatás ideje alatt az alábbi linken volt elérhető: https://neptun.ektf.hu/UniPoll/Survey.aspx?surveyid=42009302\&lng=hu-HU 


\begin{tabular}{|c|c|c|c|c|c|c|}
\hline $\begin{array}{l}\text { A kérdőív } \\
\text { fó faktorai }\end{array}$ & Példák a z i temekre & 1. & 2. & 3. & 4. & 5. \\
\hline \multirow{5}{*}{ 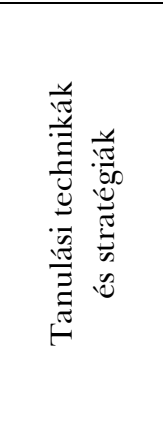 } & 25. Tanulás után átismétlem az anyagot. & $\square$ & $\square$ & $\square$ & $\square$ & $\square$ \\
\hline & $\begin{array}{l}\text { 26. Ha dolgozatra vagy vizsgára készü- } \\
\text { lök, rendszerezem a megtanultakat. }\end{array}$ & $\square$ & $\square$ & $\square$ & $\square$ & $\square$ \\
\hline & $\begin{array}{l}\text { 32. Ha szükség van rá, tanulás közben } \\
\text { is ismétlek. }\end{array}$ & $\square$ & $\square$ & $\square$ & $\square$ & $\square$ \\
\hline & 45. Az ismeretlen szavakat megkeresem. & $\square$ & $\square$ & $\square$ & $\square$ & $\square$ \\
\hline & $\begin{array}{l}\text { 33. Tanulás közben gondolattérképet } \\
\text { készítek. }\end{array}$ & $\square$ & $\square$ & $\square$ & $\square$ & $\square$ \\
\hline \multirow{4}{*}{ 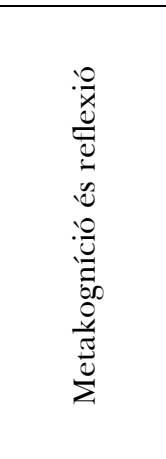 } & $\begin{array}{l}\text { 48. Ha rosszabbul teljesítek annál, amit } \\
\text { magamtól vártam, végiggondolom, } \\
\text { hol rontottam el. }\end{array}$ & $\square$ & $\square$ & $\square$ & $\square$ & $\square$ \\
\hline & $\begin{array}{l}\text { 49. Keresem az összefüggést az osztály- } \\
\text { zataim és a tanulási módszereim } \\
\text { között. }\end{array}$ & $\square$ & $\square$ & $\square$ & $\square$ & $\square$ \\
\hline & $\begin{array}{l}\text { 56. Nem megfelelő tanulmányi ered- } \\
\text { mény esetén máshogyan kezdek } \\
\text { tanulni. }\end{array}$ & $\square$ & $\square$ & $\square$ & $\square$ & $\square$ \\
\hline & $\begin{array}{l}\text { 57. Tanulás közben és a végén ellenőr- } \\
\text { zöm a tudásom. }\end{array}$ & $\square$ & $\sqcup$ & $\square$ & $\square$ & $\square$ \\
\hline
\end{tabular}

\section{Vizsgálati minta}

Jelen kutatásunkban 4 korcsoportban (9-11 év, 13-15 év, 17-19 év, 20-25 év) végeztük el a vizsgálatokat. Összesen 1257 tanuló által kitöltött komplex feladatsor volt bevonható az elemzésekbe. A hiányos vagy technikai okokból (például számítógépek technikai problémái) félbemaradt kitöltéseket nem vettük figyelembe eredményeink értékelésekor. Az online feladatok kitöltése személyenként 1,5 órát vett igénybe, kb. 20 fős csoportokban történő adatfelvétel keretében, intézményi számítógépes termekben lebonyolítva. A korcsoportok életkori eloszlása egyenletesnek mondható, egyedül a 20-25 évesek mintája alacsonyabb (2. táblázat).

2. táblázat. A különböző korcsoportok aránya a mintában

\begin{tabular}{|c|c|c|c|}
\hline Korcsoport & Átlagéletkor & Fő & Százalék \\
\hline 9-11 éves & 9,8 & 344 & 27,4 \\
\hline $13-15$ éves & 13,76 & 343 & 27,3 \\
\hline $17-19$ éves & 17,77 & 387 & 30,7 \\
\hline 20-25 éves & 21,79 & 183 & 14,6 \\
\hline Ö s s z e s e n & & 1257 & 100,0 \\
\hline
\end{tabular}


A vizsgálati minta nemi eloszlása a következőképpen alakult: A teljes mintában a fiúk-lányok aránya kiegyenlített, fiú $\mathrm{N}=585$ (a minta 56,4\%-a) lány $\mathrm{N}=672$ (a minta 53,5\%-a), de az egyes korcsoportokban a nemi megoszlás aránya váltakozó. A minta nemi megoszlása az 1. ábrán látható.

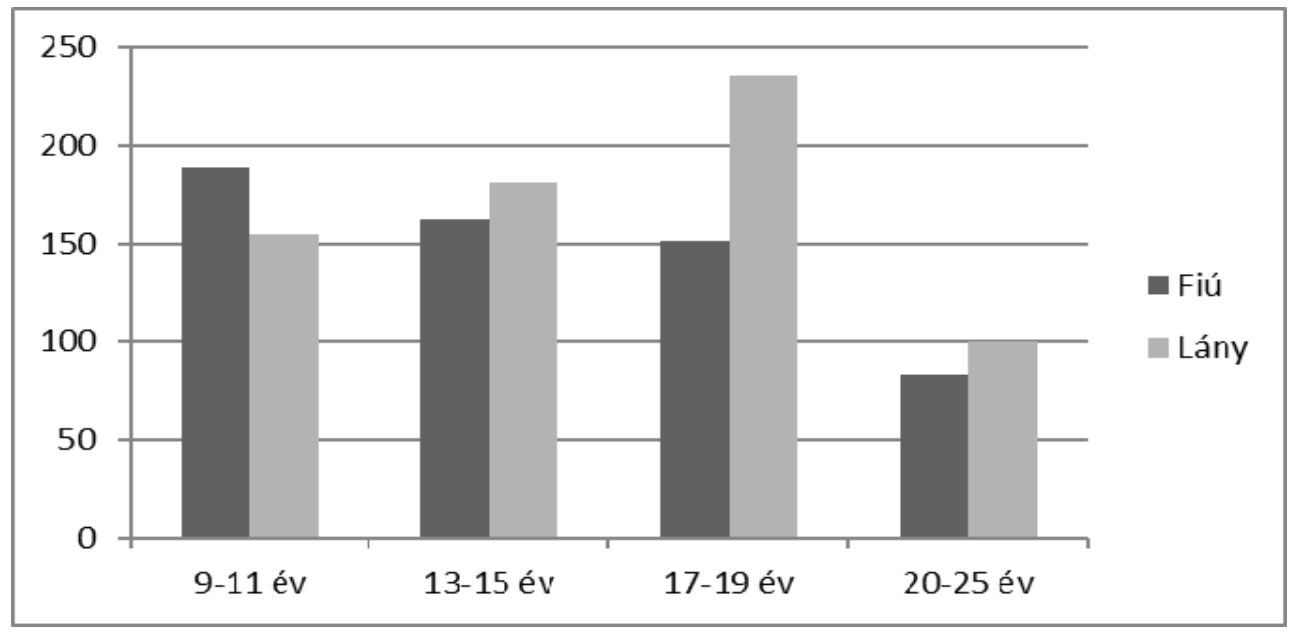

1. ábra. A minta nemi megoszlása a különböző korcsoportokban

A 9-11 éveseknél a fiúk vannak többen (54,8\%). Egy 2006-ban befejezett kutatás szerint a nőnemű élve született csecsemők aránya világátlagban 48,6 százalék, és a fiúk aránya a fejlett országokban is a születési hely földrajzi szélességével arányosan nő (lásd Semmelweis figyelő). A 13-15 éveseknél ez az arány megfordul, de itt a legkiegyenlítettebb a nemek aránya (fiú: 47,2\%, lány: 52,8\%). A középiskolás 17 19 éves korosztálynál pedig a lányok aránya magasabb (61\% lány, 39\% fiú). A középiskolás korosztályban a nemek arányának eltolódását az adja, hogy a mintában szereplő középfokú intézmények nagyobbrészt gimnáziumok, ahol országosan is magasabb a lányok aránya (57\%) (oktatási adatok 2014/15, KSH).

\section{A szülók legmagasabb iskolai végzettsége}

A tanulók szüleinek iskolai végzettsége tekintetében azt láthatjuk (2. és 3. ábra), hogy a középfokú végzettséggel rendelkezők aránya mind az édesanyáknál, mind az édesapáknál kiemelkedik, de a felsőfokú végzettséggel rendelkezők aránya is magas, különösen a 13-15 és a 17-19 éves korosztálynál. 


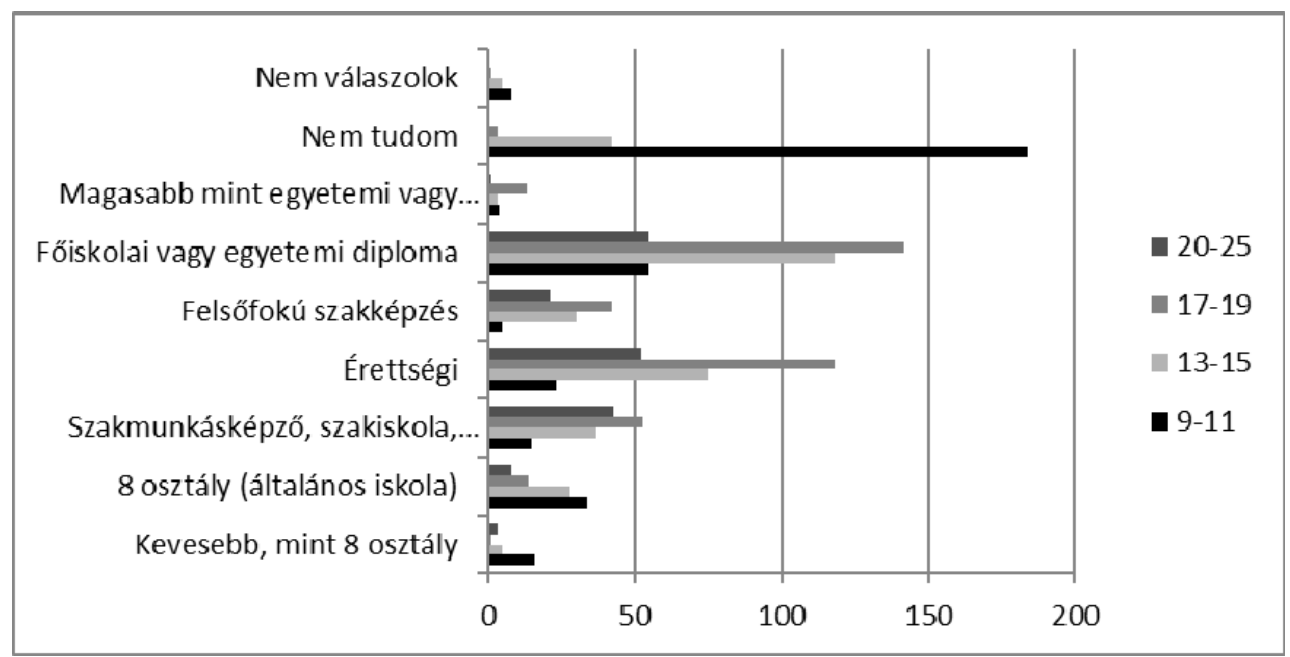

2. ábra. Az édesanya legmagasabb iskolai végzettsége korcsoportonként

A középiskolás tanulók édesapja esetében sokkal gyakoribb a szakmunkásképző vagy szakiskolai végzettség.

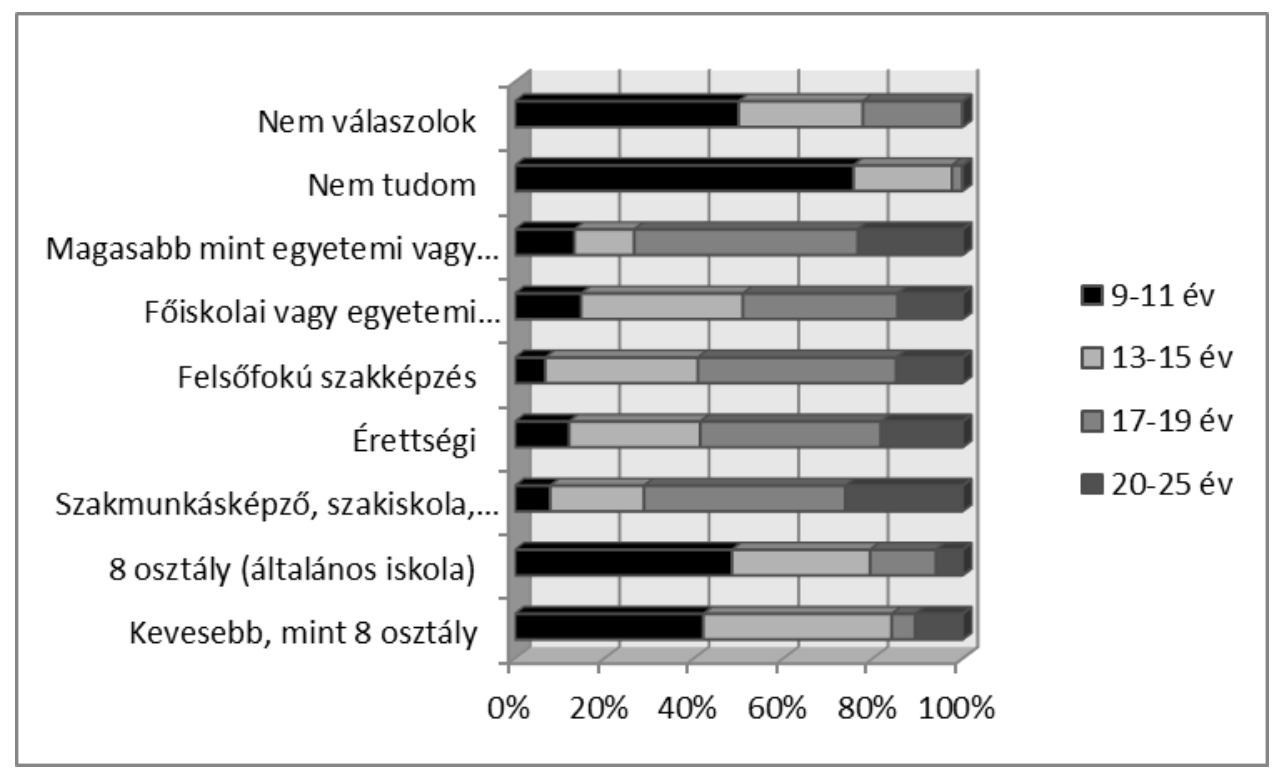

3. ábra. Az édesapa legmagasabb iskolai végzettsége korcsoportonként 
Azt is megállapíthatjuk, hogy 9-11 évesek számára a szülők legmagasabb iskolai végzettsége gyakran nem ismert, vagy nem ezekkel a kifejezésekkel tudnak róla, mert az iskolai végzettség kérdésére igen gyakran „nem tudom” választ adtak.

\section{A lakhely típusa szerinti megoszlás}

A vizsgálatban részt vevő tanulók zömében Eger város köznevelési intézményeibe és főiskolájára járnak. Ebből a szempontból a minta nem tekinthető reprezentatívnak. (Mindössze egy budapesti intézmény van a mintában.) A kérdésekre adott válaszokból kitűnik, hogy a városban élók aránya a legnagyobb (összevonva az egyéb város és megyeszékhely adatait) összesen 56,5 \% (380+330fő). Ezt követően falun, községben élnek a legtöbben, 33,8\% ( $\mathrm{N}=425)$. A fóvárosban él a vizsgálati személyek 9\%-a $(\mathrm{N}=113)$, és tanyán, kisközségben él 4 fő $(0,3 \%)$, nem tudta besorolni a lakóhelye típusát 5 fó $(0,4 \%)$.

3. táblázat. A lakhely típusa korcsoportonként

\begin{tabular}{|c|c|c|c|c|c|}
\hline \multirow{2}{*}{ A lakhely típusa } & \multicolumn{4}{|c|}{ Korcsoport } & \multirow{2}{*}{ Összesen } \\
\hline & 9-11 év & 13-15 év & 17-19 év & 20-25 év & \\
\hline Falu, község & 109 & 122 & 139 & 55 & 425 \\
\hline Tanya, kisközség & 1 & 1 & 1 & 1 & 4 \\
\hline Megyeszékhely & 114 & 114 & 113 & 39 & 380 \\
\hline Egyéb város & 84 & 82 & 91 & 73 & 330 \\
\hline Főváros & 31 & 24 & 43 & 15 & 113 \\
\hline Nem tudom & 5 & 0 & 0 & 0 & 5 \\
\hline Összesen & 344 & 343 & 387 & 183 & 1257 \\
\hline
\end{tabular}

Ahogy azt a 3. táblázatban láthatjuk, a lakhely szerinti megoszlás többé-kevésbé egyenletes a mintánkban szereplő korcsoportokban. A fővárosi lakhely a 17-19 éveseknél a leggyakoribb, és a „nem tudom” válasz csak a legfiatalabb korosztálynál fordult elö (5 fö).

\section{VIZSGÁLATI EREDMÉNYEK}

Cikkünkben a kérdőíves vizsgálat és a tanulmányi eredményességre vonatkozó adatok dokumentumelemzésének eredményeit mutatjuk be. A kutatási adatok feldolgozása SPSS program segítségével történt. A leíró statisztikai próbák mellett korrelációszámításokat, varianciaanalízist, faktoranalízist és kétmintás $t$-próbákat végeztünk az összefüggések feltárására. 
Az online kérdőíves vizsgálat eredményei - az internethasználat jellegzetességei

a) Hétköznapokon tanulmányi időszakban és szünetekben

Kérdőívünk első részében 7 kérdés az infokommunikációs eszközök használatára vonatkozott. Az adatokból látható, hogy a különböző korcsoportokban folyamatosan emelkedik az átlagos hétköznapi internethasználat mennyisége (4. ábra). Míg 10 éves kor körül 1-1,5 órát neteznek a tanulók naponta, addig ez fokozatosan megduplázódik 20 éves korra. A legjelentősebb emelkedés a 10 és 14 éves kor között van.

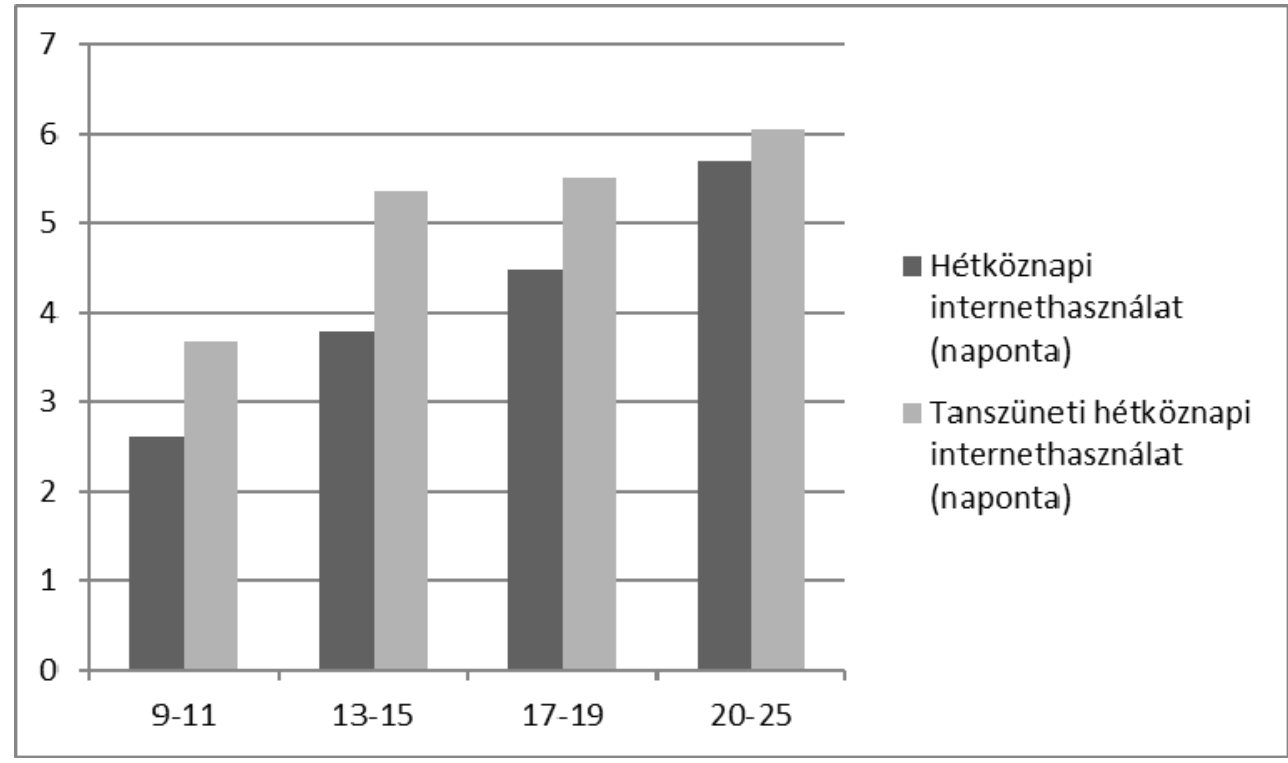

4. ábra. Az internethasználat mennyisége hétköznapokon a különböző korcsoportokban (a függőleges tengelyen $1=0-30$ perc, $2=30-60$ perc, $3=60-90$ perc, $4=90-120$ perc, $5=120-150$ perc, $6=150-180$ perc)

Míg a fiatalabb korcsoportok tanítási szünetekben a tanítási héthez képest legalább fél órával többet neteznek, addig ez a különbség eltűnik 20 éves korra. Az internethasználat mennyisége hétvégi napokon minden korcsoportnál meghaladja a hétköznapi használatot átlagosan napi fél órával. Kivétel a 20-25 éves korosztályt, ahol a hétköznapi használatnál már tárgyalt magas használati átlag nem változik. 
b) A tanulási céllal történő internethasználat mennyisége a különbözö IKT-eszközökön

Ahogyan az 5. ábrán láthatjuk, az egyes IKT-eszközök iskolában történő tanulási célú használata a különböző korosztályokban eltérő tendenciákat mutat. Miközben az asztali számítógép használata még mindig eléggé elterjedt az összes életkori csoportban, észrevehetjük a laptop (hordozható számítógép) kiugró használati arányát a 20 éves vagy annál idősebb tanulóknál, akik (főként felsőoktatási hallgatók révén) napi szinten használják ezeket az eszközöket az iskolában. Ugyancsak figyelemre méltó a tabletek növekvő használata (itt az iPadet külön vizsgáltuk, mivel egy jóval drágább és még egyszerủbb használattal rendelkező táblagépről beszélünk). Ami a legszembetűnőbb, hogy a tabletek mellett az okostelefonok használati aránya is meredeken (és egyenletesen) nő, ami a leggyakrabban használt eszközzé teszi azokat (legalább hetente egyszer használják az iskolában tanulási célból).

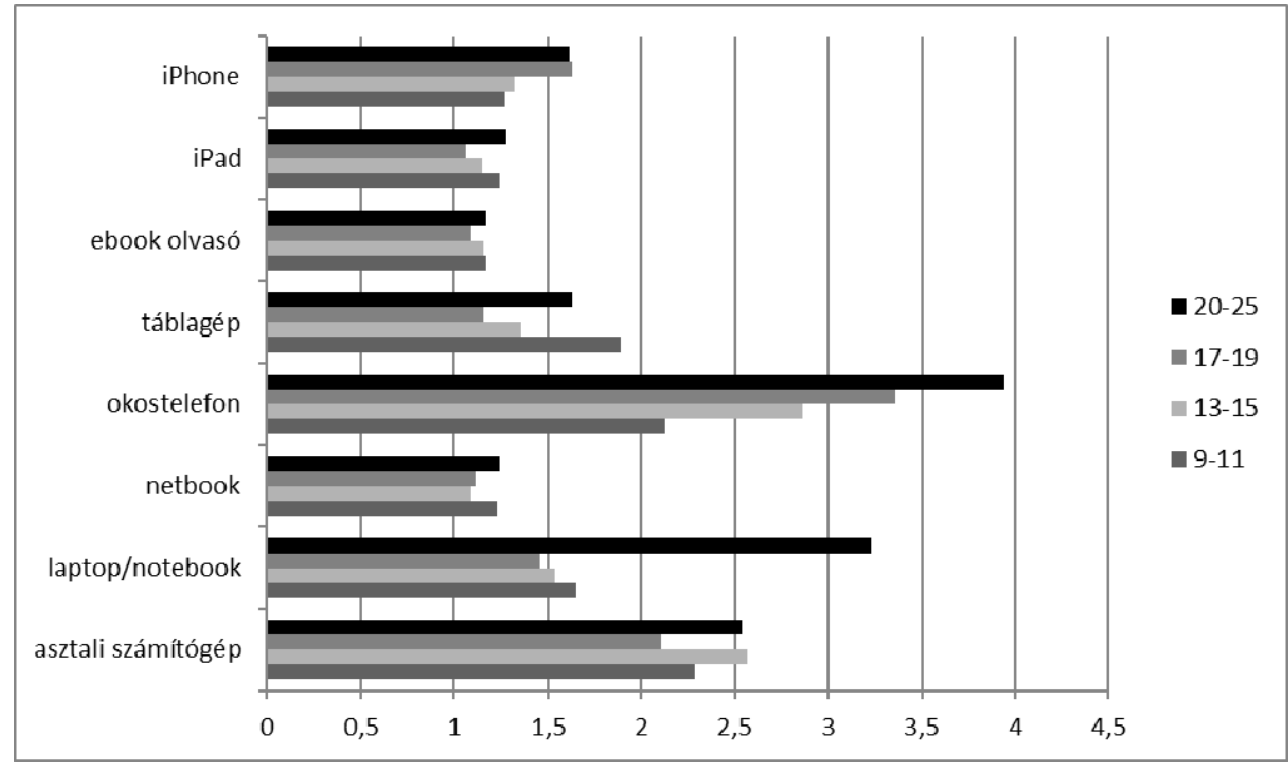

5. ábra. Tanulási célú iskolai IKT-használat a különböző korcsoportokban (soha $=1$, évente néhányszor $=2$, havonta egyszer $=3$, hetente egyszer $=4$, naponta $=5$, naponta többször $=6$ )

A tanulók otthonukban az iskolaihoz hasonló gyakorisággal használják az asztali számítógépet, netbookot, iPadet és iPhone-t, az iskolainál gyakrabban használják viszont a tabletet, az okostelefonjukat pedig már a 13-15 évesek is gyakrabban használják otthon, és ez a használati gyakoriság érdemben már nem is változik, ahogyan az idősebb tanulók felé haladunk. 
c) Otthoni tanulás közbeni párhuzamos aktivitás

Online kérdőívünkben rákérdeztünk a párhuzamos feladatvégzés közbeni figyelmi váltások gyakoriságára is: A 6. ábra bemutatja, hogy a filmnézés kivételével minden korosztályban egyre nő a neten szörfözés, beszélgetés, közösségi oldalak használata és a zenehallgatás céljából történő tanulás közbeni aktivitások előfordulása, a filmnézés azonban a legfiatalabb korosztálynál a leggyakoribb tanulás közben.

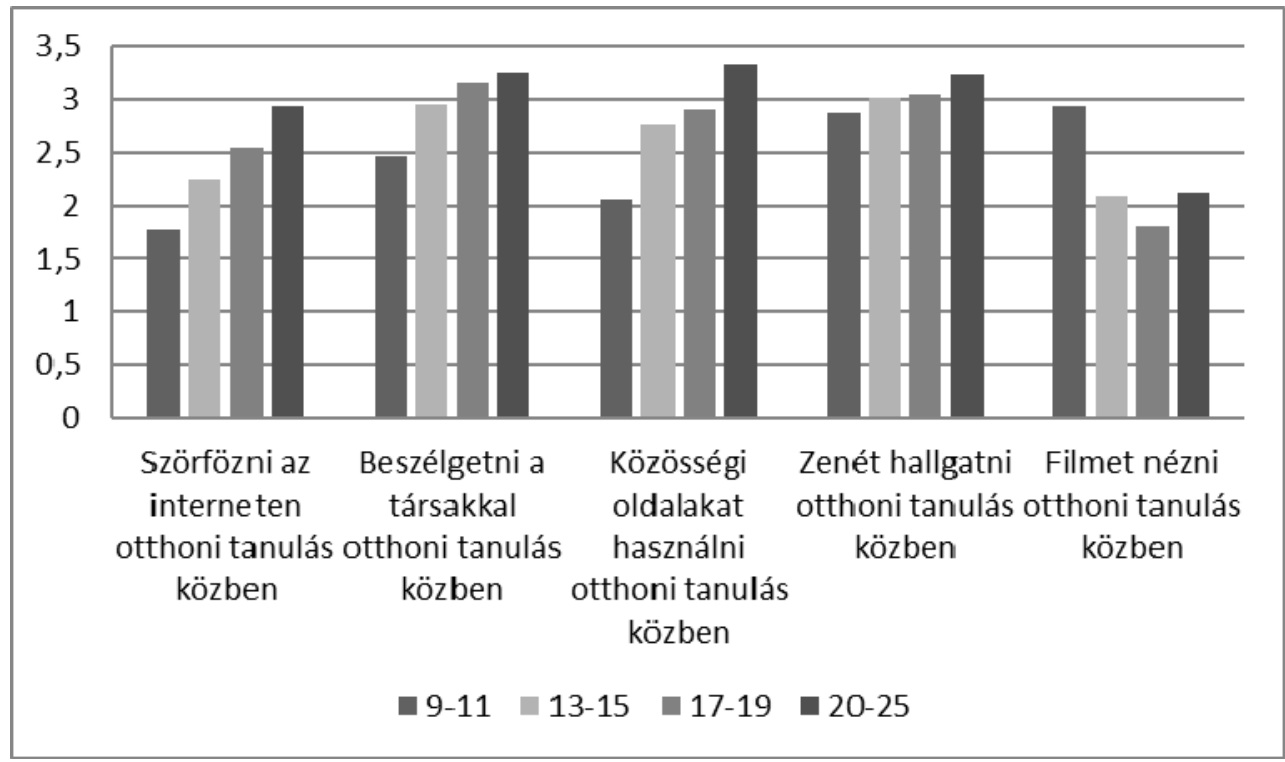

6. ábra. IKT-eszközökhöz kapcsolódó tanulás alatti párhuzamos aktivitások gyakorisága ( 1 =soha, $2=$ ritkán, $3=$ alkalmanként, $4=$ gyakran, $5=$ szinte mindig $)$

d) IKT-eszközök használatának célja

A 7. ábrán láthatjuk az IKT-eszközök használati célját tanulás közben. A különböző célok korosztályonként hasonló arányokat mutatnak, és az idő előrehaladtával egyre gyakrabban is alkalmazzák ezekre a célokra az eszközöket. A leggyakrabban tananyagok megosztására, cseréjére, nyelvtanulásra, valamint idegen szavak és plusz ismeretek keresésére használják tanulás közben az infokommunikációs technológiát a fiatalok. A prezentációk készítése is egyre gyakoribbá válik, ahogy közeledünk a főiskolás korosztály felé. Érdemes lenne akár eszközönként is megvizsgálni a használati jellemzőket, mivel elég gyakran látunk például a mobiltelefonjaikon szótárt használó tanulókat, amit valószínủleg a gyors keresés lehetősége magyaráz. 
A nem tanulási célú IKT-használat elemzésekor azt láthatjuk, hogy míg a netbook, e-book olvasó, iPad és iPhone használata elhanyagolható, addig az asztali számítógépeket legalább havi egyszer, a laptopot - különösen a 20 év felettiek már napi szinten használják ilyen célokra. Ez a mintázat az okostelefonnál már 13-15 éveseknél is megfigyelhető, de már a 10 évesek is legalább hetente használják.

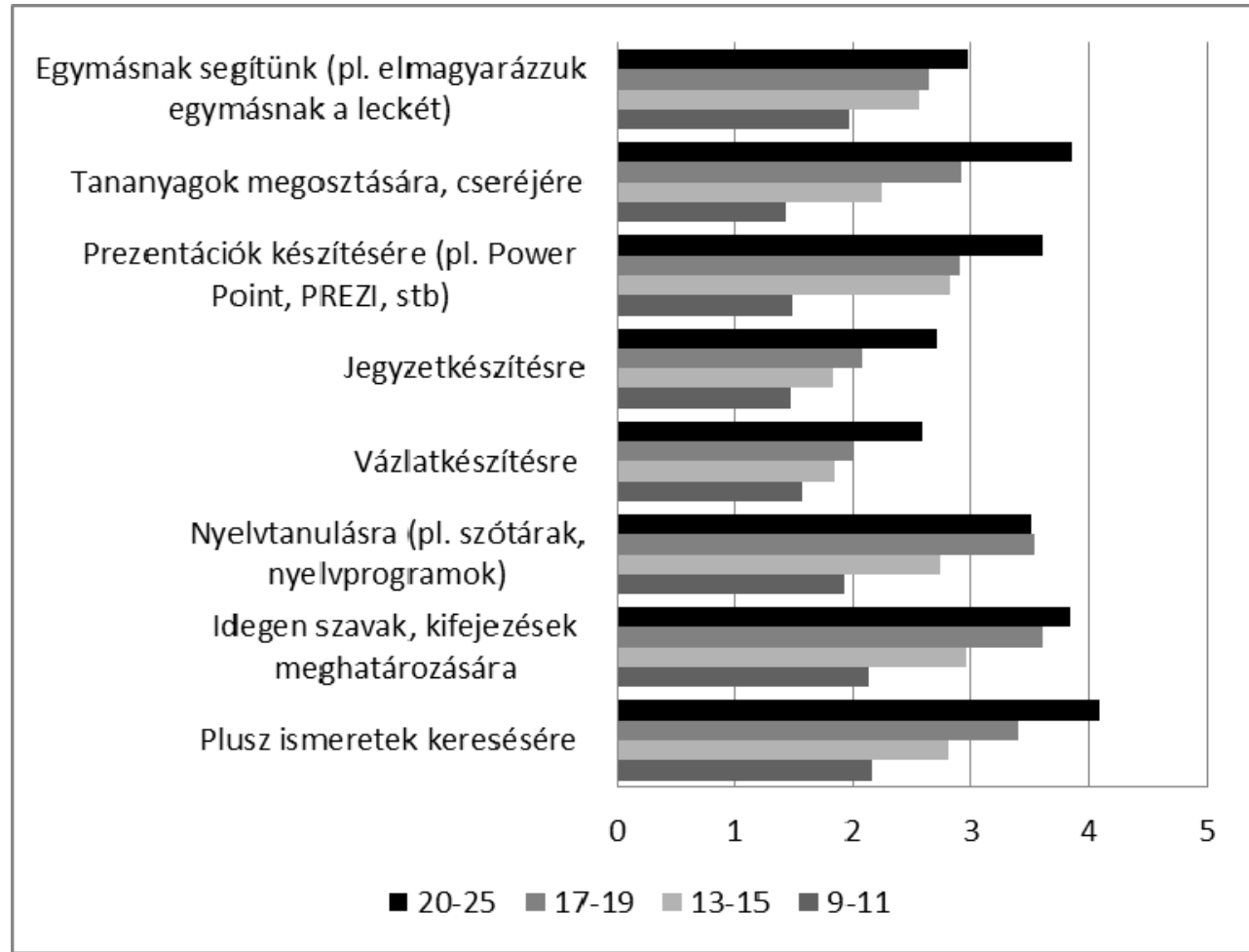

7. ábra. IKT-eszközök használatának célja tanulás közben

( 1 =soha, $2=$ ritkán, $3=$ alkalmanként, $4=$ gyakran, $5=$ nagyon gyakran)

Az online kérdőives vizsgálat eredményei - az önszabályozó tanulás kérdöive

Az önszabályozó tanulás szempontjából vizsgálva az online kérdőív eredményeit, szignifikáns különbségeket találtunk a korcsoportok között (4. táblázat). Elmondható, hogy az életkor előrehaladtával egyre fejlettebbé válik a tanulás önszabályozása. A mi eredményeink nem támasztják alá Molnár Éva (2002) tapasztalatait, aki a 8. és 11. évfolyamokat összehasonlítva azt találta, hogy az életkor előrehaladtával az eredményekben csökkenő tendencia figyelhető meg, a 11. évfolyam gyengébb eredményt produkált az önszabályozó tanulási készségek több területén. A mi 
214 Dávid M. - Taskó T. - Héjja-Nagy K. - Mester D. - Dorner L. - Estefánné Varga M.

\begin{tabular}{|c|c|c|c|c|c|c|c|c|c|c|c|c|c|c|c|c|c|}
\hline 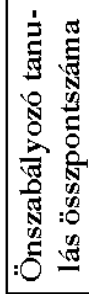 & 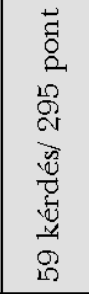 & 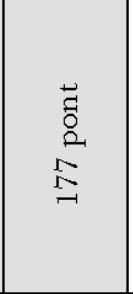 & 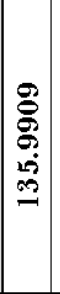 & 웡 & $\begin{array}{l}\infty \\
\infty \\
1 \\
1 \\
5 \\
0 \\
0 \\
\infty\end{array}$ & 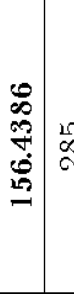 & 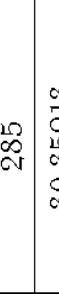 & 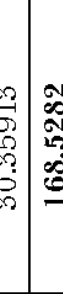 & $\mid \begin{array}{l}\Omega \\
\infty \\
\infty \\
\infty\end{array}$ & 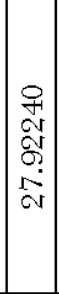 & 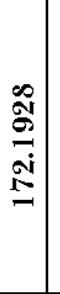 & 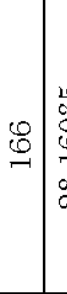 & 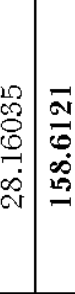 & : & 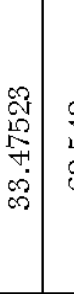 & $\begin{array}{l}\text { Oे } \\
\text { H̃ } \\
\text { ov } \\
0\end{array}$ & $\stackrel{8}{\circ}$ \\
\hline 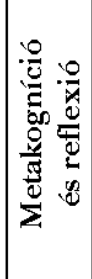 & 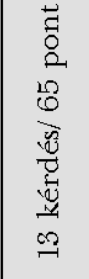 & $\begin{array}{l}\vec{z} \\
0 \\
2 \\
\text { ه }\end{array}$ & 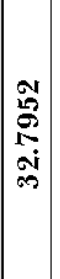 & 足 & 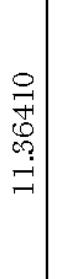 & 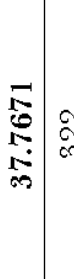 & 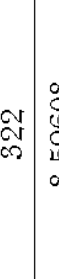 & 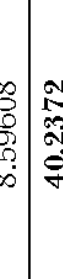 & 质 & 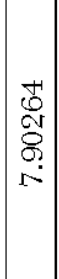 & 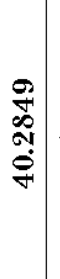 & 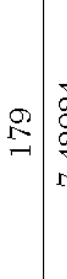 & 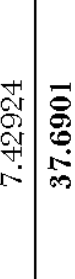 & $\begin{array}{ll}0 \\
0 \\
= \\
=\end{array}$ & 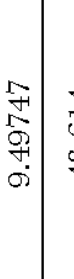 & $\begin{array}{l}\vec{H} \\
0 \\
0 \\
\stackrel{7}{7}\end{array}$ & $\stackrel{8}{\circ}$ \\
\hline 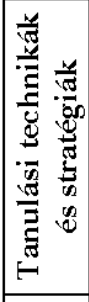 & 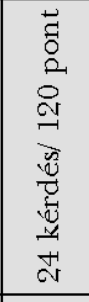 & $\begin{array}{l}\vec{z} \\
\text { م. } \\
\text { N } \\
\text { N }\end{array}$ & $\mid \begin{array}{l}0 \\
2 \\
\infty \\
8 \\
0 \\
0\end{array}$ & 足 & 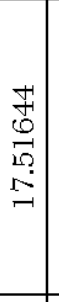 & 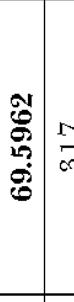 & 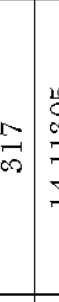 & 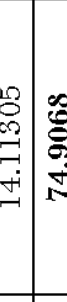 & $\begin{array}{l}10 \\
\infty \\
\infty\end{array}$ & $\mid \begin{array}{c}\mathcal{F} \\
\vec{G} \\
\mathcal{S} \\
\mathcal{i} \\
\mathcal{G}\end{array}$ & 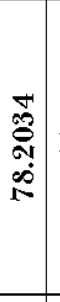 & $\underline{\Sigma}$ & 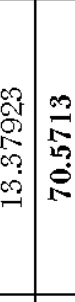 & 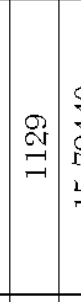 & 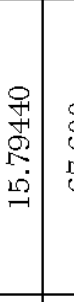 & $\begin{array}{l}8 \\
\stackrel{8}{0} \\
\stackrel{0}{0}\end{array}$ & $\stackrel{8}{\circ}$ \\
\hline 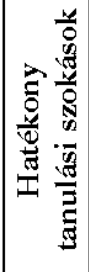 & 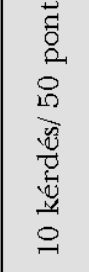 & 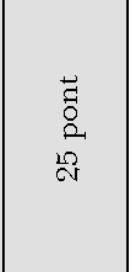 & 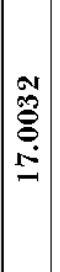 & $\begin{array}{c}o v \\
\cdots \\
\infty\end{array}$ & 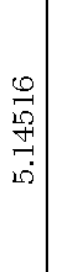 & 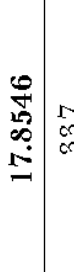 & 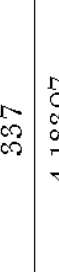 & 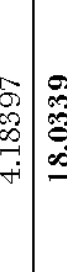 & $\begin{array}{l}\mid \\
\infty \\
\infty \\
\infty\end{array}$ & 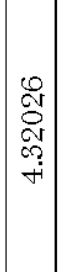 & $\begin{array}{l}0 \\
0 \\
b \\
0 \\
0 \\
0 \\
0\end{array}$ & 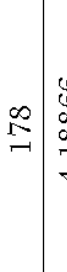 & 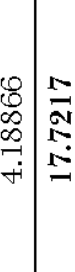 & $\begin{array}{ll}\vec{\sim} \\
\vec{\sim} \\
\rightarrow\end{array}$ & \begin{tabular}{c|c}
0 \\
0 \\
0 \\
0 \\
0 \\
0 \\
+ \\
+
\end{tabular} & $\underset{\infty}{\stackrel{+}{Q}}$ & $\overrightarrow{\bar{\theta}}$ \\
\hline 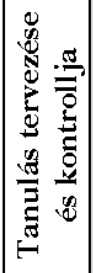 & 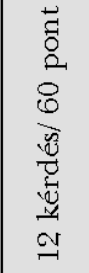 & $\begin{array}{l}\vec{z} \\
0 \\
o \\
o \\
o\end{array}$ & 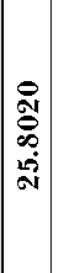 & $\begin{array}{c}\infty \\
\infty \\
\infty \\
\infty\end{array}$ & 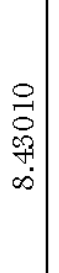 & 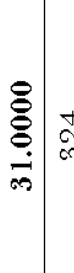 & 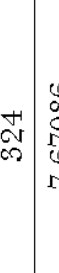 & $\begin{array}{ll}0 \\
0 \\
0 \\
0 \\
0 \\
0 \\
0\end{array}$ & $\underset{\infty}{R}$ & 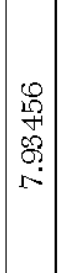 & $\begin{array}{l}\frac{\theta}{\sigma} \\
\frac{1}{10} \\
\Delta \\
0\end{array}$ & 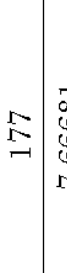 & 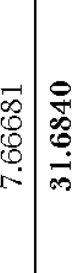 & 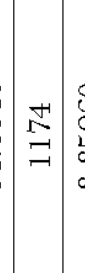 & $\begin{array}{l}8 \\
8 \\
0 \\
1 \\
\infty \\
\infty \\
\infty\end{array}$ & 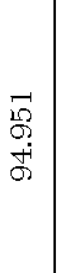 & $\stackrel{8}{8}$ \\
\hline $\begin{array}{c}0 \\
0 \\
0 \\
0 \\
0 \\
0 \\
0 \\
0 \\
0 \\
0 \\
0 \\
-1\end{array}$ & 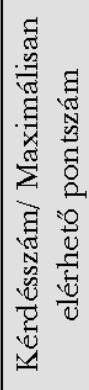 & 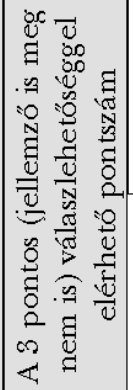 & 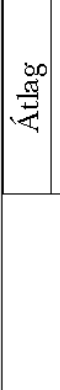 & 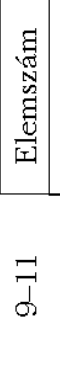 & 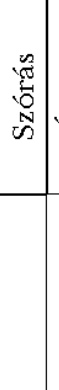 & 蛋 & 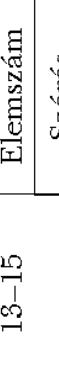 & 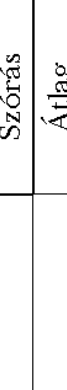 & 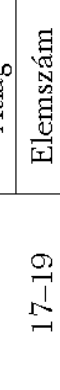 & 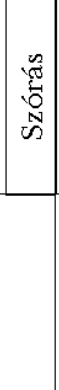 & 充 & 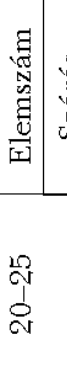 & 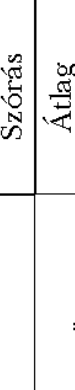 & 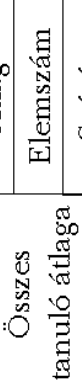 & 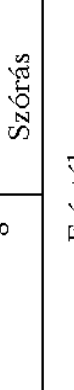 & 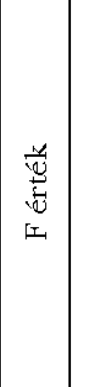 & 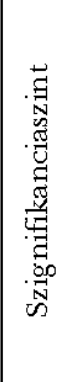 \\
\hline
\end{tabular}


vizsgálatunkban a kérdőív szinte minden faktorában egyenletes növekedést tapasztaltunk a korcsoportok között. A Tanulás tervezése és kontrollja, valamint a Metakogníció és reflexió faktoroknál az figyelhető meg, hogy a középiskola végére már kialakulnak az önszabályozó tanulásnak ezen elemei, és a későbbiekben csak minimálisan változnak (8. ábra).

A 4. táblázat azt is jól szemlélteti, hogy a metakogníció és önreflexió fejlődése területén a 10-14 év között van a legnagyobb ugrás, majd a középiskolában egy mérsékeltebb ütemủ fejlődés, amely a középiskola végére beáll, valószínủ, hogy spontán fejlődés a továbbiakban nem várható (8. ábra). Az önszabályozó tanulás két faktorának, a metakognitív és önreflektív gondolkodásmódnak és a tanulás tervezésének és kontrolljának a tervszerű fejlesztésére van szükség ahhoz, hogy ezek a sajátosságok jellemzőbbek legyenek a tanulás során.

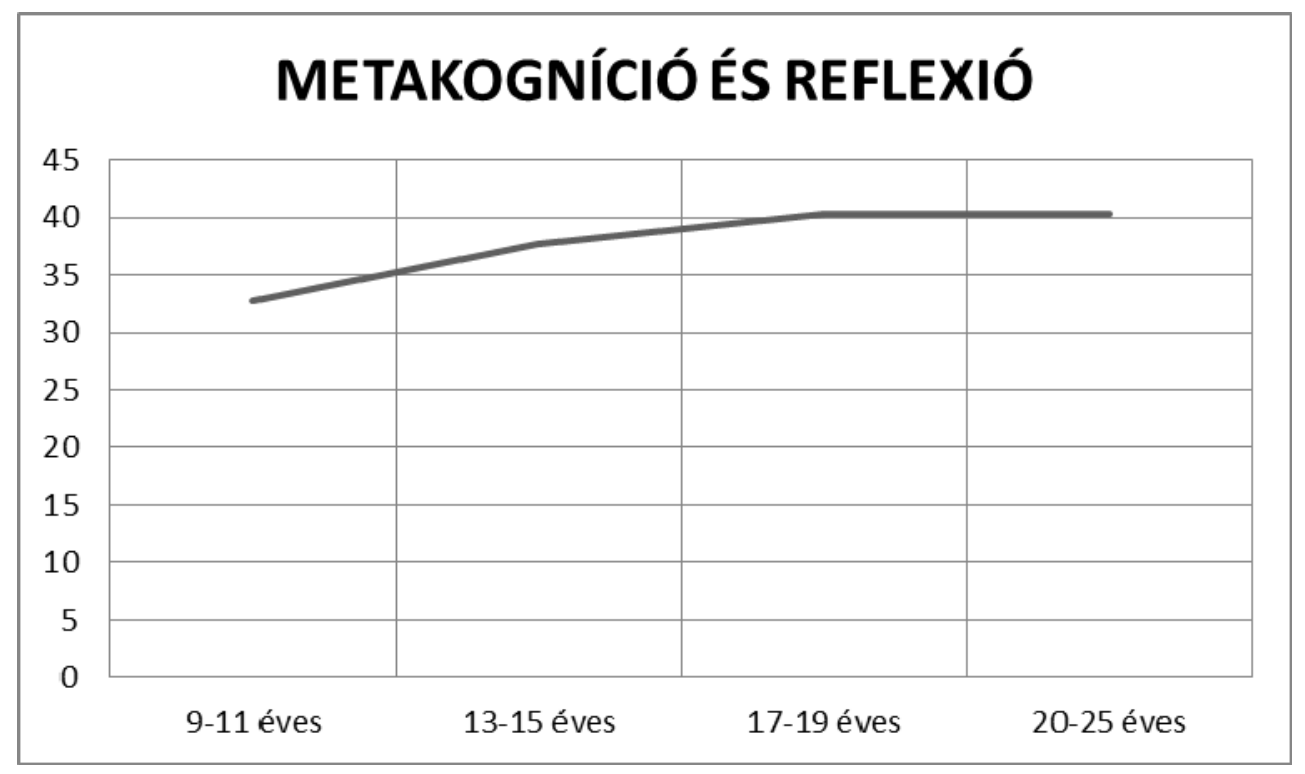

8. ábra. A metakogníció és önreflexió fejlődése 10-22 éves kor között

A tanulási technikák, stratégiák alkalmazása azonban tovább bővül, a felsőoktatásba kerülvén még több tanulási technikát alkalmaznak a hallgatók, mint a gimnazisták. Egyedül a tanulási szokások terén nincs változás, végig nagyon alacsony pontszámot ért el minden csoport (4. táblázat). Olyan kérdések szerepeltek itt, mint a tanulás rendszeressége, a pihent állapotban történő tanulás, a tantárgyak tanulásának optimális sorrendje, a tanulás helyének rendezettsége. Az adatok alapján elmondható, hogy a tanulási szokások már kisiskolás korban megalapozódnak, és a későbbiek során nehezen változnak. Az eredmények értelmezéséhez 
érdemes a maximálisan megszerezhető pontokhoz viszonyítani a kapott átlagokat. Tekintettel arra, hogy 5 fokú skálán jelezhették a tanulók az állításokkal való egyetértésüket, vagy egyet nem értésüket, a kérdőívben szereplő állítások úgy vannak megfogalmazva, hogy az önszabályozó tanulásra jellemző optimális érték a 4 pontos, ,jellemző”, vagy az 5 pontos, „teljes mértékben jellemző” válasz lenne. A 4. táblázatban megjelenítettük a maximális, és a 3 pontos (jellemző is meg nem is) válaszlehetőséggel elérhető pontszámokat is. Látható, hogy még a legmagasabb értékeket mutató 20-25 éves korosztály is éppen csak hogy eléri ezt az eredményt a tanulás tervezése, kontrollja és a metakogníció területén. A tanulási szokások terén pedig minden csoport átlaga mélyen alatta marad a közepes szintnek. Elmondható, hogy valamennyi korosztályra jellemző, hogy tanulási szokásrendszerük nem támogatja a tanulást. Nem tartanak maguk körül rendet, nem pihennek tanulás előtt, nem tudják, hogy a tantárgyak tanulási sorrendjének kialakításánál mire kell figyelniük. Egyedül a tanulási technikák és stratégiák alkalmazása terén figyelhető meg, hogy a középiskolás és főiskolás korosztály elmozdul pozitív irányba, a tanulási technikák egyre inkább jellemző használata felé.

Bár minden korcsoport átlaga alacsony az önszabályozó kérdőív faktoraiban, mégis elmondható, hogy leginkább a 17-19 éves és a 20-25 éves korosztály tervezi meg és kontrollálja tanulását, ők alkalmazzák a különböző tanulási technikákat, stratégiákat, valamint ők tudnak már metakognitív szinten is gondolkodni saját tanulásukról. A legkevésbé a 9-11 éves korosztálynál jelennek meg az önszabályozó tanulás jellemzői, de ez a korosztály sajátosságainak megfelelő, nekik még nagyobb szükségük van a tanulás külső irányítására.

\section{A tanulmányi eredményesség összefüggései az önszabályozó tanulás fejlettségével}

Annak megítélésére, hogy az önszabályozó tanulás fejlettsége hogyan hat a tanulmányi eredményekre, a kérdőívében kapott adatokat korreláltattuk a tanulmányi átlagokkal és a matematika és szövegértés kompetenciamérési eredmények közül a sztenderdizált képességpontok adataival. A kapott eredményeket az 5. táblázat szemlélteti. Az önszabályozó tanulás faktorai erős, kölcsönös kapcsolatot mutatnak egymással és az önszabályozó tanulás összpontszámmal. Ez mutatja a kérdőív koherenciáját, melyet a kérdőíven végzett faktoranalízis eredményei is alátámasztanak. A tanulmányi adatokkal összevetve a kérdőívben kapott pontszámokat már jóval mérsékeltebb, de erősen szignifikáns eredményeket kaptunk. A tanulók tanulmányi átlaga szignifikáns korrelációt mutat az önszabályozó tanulás kérdőívének minden egyes faktorával, bár ez a kapcsolat nem mondható túl erősnek. A matematikai és szövegértési képességek fejlettsége szorosabb kapcsolatban van az önszabályozó tanulás fejlettségével. Leginkább a tanulás tervezése és kontrollja jár együtt a kompetenciamérési eredményekkel. Valószínü, hogy akik jobban tervezik és kontrollálják tanulási tevékenységüket, azok a kompetenciamérés feladathelyzetét is hatékonyabban kezelik, az idővel jobban bánnak, ezért jobban átlátják a szituációt, jobban beosztják a feladatokat, így jobban is teljesítenek. 
Önszabályozó tanulás - tanulási eredményesség - IKT

\begin{tabular}{|c|c|c|c|c|c|c|c|c|}
\hline 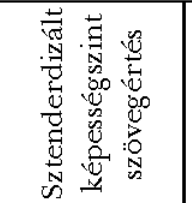 & $\begin{array}{l}* \\
0 \\
y \\
y \\
0 \\
0\end{array}$ & $\begin{array}{l}\text { of } \\
\text { \&े } \\
\text { o }\end{array}$ & $\frac{\stackrel{*}{8}}{6}$ & 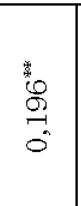 & $\begin{array}{l}\text {. } \\
\infty \\
8 \\
8 \\
0 \\
0\end{array}$ & $\begin{array}{l}3 \\
\vdots \\
0 \\
0 \\
0 \\
0\end{array}$ & $\begin{array}{l}* \\
\infty \\
\infty \\
0 \\
0 \\
0\end{array}$ & - \\
\hline 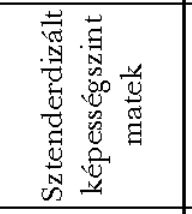 & 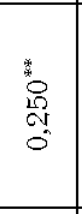 & $\begin{array}{l}\overrightarrow{+} \\
\stackrel{8}{0} \\
\stackrel{1}{1}\end{array}$ & $\begin{array}{l}\text { 善 } \\
\stackrel{8}{\circ} \\
\\
\end{array}$ & $\frac{\sqrt[*]{2}}{D}$ & $\begin{array}{l}\stackrel{1}{1} \\
\stackrel{0}{\infty} \\
\stackrel{0}{6}\end{array}$ & $\begin{array}{l}3 \\
0 \\
0 \\
18 \\
0 \\
0\end{array}$ & - & 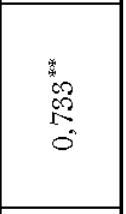 \\
\hline 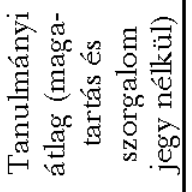 & $\begin{array}{l}* \\
8 \\
0 \\
0 \\
0 \\
0\end{array}$ & $\stackrel{*}{\stackrel{*}{\sigma}}$ & $\begin{array}{l}\text { 盖 } \\
\stackrel{9}{\circ}\end{array}$ & 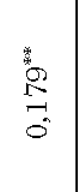 & $\frac{1}{5}$ & - & 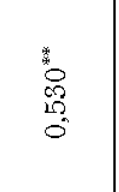 & 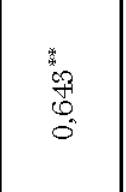 \\
\hline 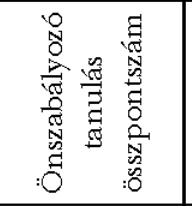 & \begin{tabular}{l}
$*$ \\
\multirow{2}{*}{} \\
0 \\
0 \\
0 \\
0 \\
0
\end{tabular} & $\begin{array}{l}0 \\
0 \\
8 \\
0 \\
0\end{array}$ & 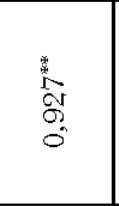 & 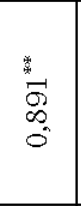 & - & $\frac{\stackrel{0}{*}}{0}$ & $\begin{array}{l}\stackrel{*}{*} \\
\infty \\
\infty \\
0 \\
0\end{array}$ & $\begin{array}{l}{ }^{*} \\
\stackrel{8}{8} \\
8 \\
0 \\
0\end{array}$ \\
\hline 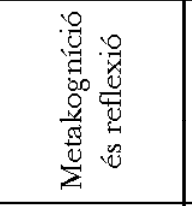 & $\begin{array}{l}{ }^{*} \\
8 \\
8 \\
0 \\
0\end{array}$ & $\begin{array}{l}\text { ". } \\
0 \\
0 \\
0 \\
0 \\
0 \\
0\end{array}$ & $\begin{array}{l}\stackrel{*}{R} \\
\stackrel{8}{R} \\
0\end{array}$ & - & 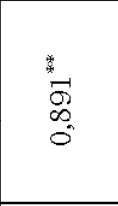 & $\frac{.}{\stackrel{2}{\circ}}$ & $\frac{\stackrel{*}{*}}{\vec{n}}$ & $\frac{*}{8}$ \\
\hline 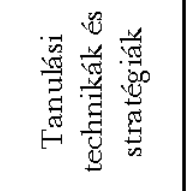 & $\begin{array}{l}* \\
6 \\
8 \\
0 \\
0 \\
0\end{array}$ & $\begin{array}{l}\text { w } \\
0 \\
0 \\
0 \\
0 \\
0\end{array}$ & - & $\begin{array}{l}{ }_{0}^{*} \\
\frac{8}{5} \\
0 \\
0\end{array}$ & 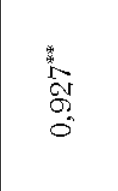 & $\begin{array}{l}\stackrel{*}{8} \\
\stackrel{1}{0}\end{array}$ & $\stackrel{*}{\stackrel{*}{8}}$ & $\begin{array}{l}8 \\
8 \\
0 \\
0\end{array}$ \\
\hline 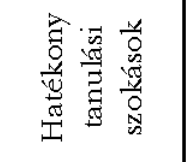 & $\begin{array}{l}* \\
8 \\
8 \\
0 \\
0 \\
0\end{array}$ & - & $\begin{array}{l}* \\
0 \\
01 \\
10 \\
0 \\
0\end{array}$ & 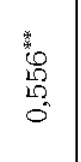 & $\begin{array}{l}.0 \\
8 \\
0 \\
0 \\
0\end{array}$ & $\stackrel{\text { 奠 }}{=}$ & $\stackrel{\overrightarrow{8}}{8}$ & $\begin{array}{l}\text { ov } \\
\text { ov } \\
0 \\
0\end{array}$ \\
\hline 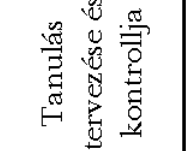 & $\rightarrow$ & 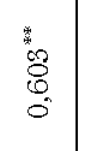 & 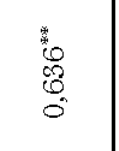 & $\begin{array}{l}: 0 \\
: 8 \\
0 \\
0 \\
0\end{array}$ & $\begin{array}{l}\text { 采 } \\
\infty \\
\infty \\
0 \\
0 \\
0\end{array}$ & 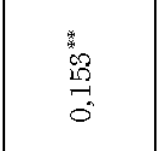 & $\begin{array}{l}* \\
0 \\
0 \\
0 \\
0 \\
0\end{array}$ & $\begin{array}{l}y^{2} \\
0 \\
y \\
y \\
0 \\
0 \\
0\end{array}$ \\
\hline & 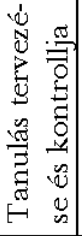 & 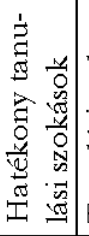 & 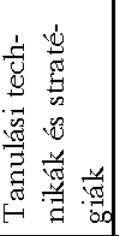 & 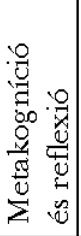 & 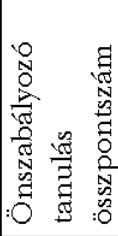 & 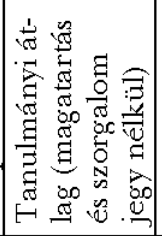 & 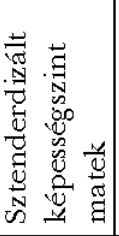 & 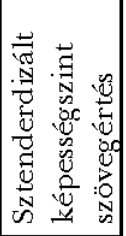 \\
\hline
\end{tabular}


Gyengébb, de szignifikáns kapcsolat található a tanulmányi átlag valamint a kompetenciamérési eredmények és a kérdőív Metakogníció és a Tanulási technikák, stratégiák faktorai között is. Egyedül a Tanulási szokások faktor nem befolyásolja a kompetenciamérési eredményeket, a tanulmányi átlaggal viszont mégis van egy gyenge, de szignifikáns együttjárása. Az adatok arra engednek következtetni, hogy a tanulással kapcsolatos konkrét tervek, az ellenőrzés, a tanulási technikák és stratégiák alkalmazása, illetve az ezekre vonatkozó metakogníció, reflexió inkább befolyásolják a képességek megfelelő szintű alkalmazását, mint a tanulási szokásrendszer.

A tanulási eredményeknek az önszabályozó tanulási kérdőív valamennyi mutatójával történő szignifikáns együttjárása mégis megengedhetővé teszi azt az óvatos következtetést, hogy az önszabályozó tanulás képességeinek fejlesztésével hozzájárulhatnánk a tanulói teljesítmények javulásához.

\section{Az infokommunikációs eszközök használatának sajátosságai és az önszabályozó tanulás fejlettsége közötti összefüggés}

Annak érdekében, hogy meg tudjuk vizsgálni az infokommunikációs eszközök használati gyakorisága és az önszabályozó tanulás fejlettsége közötti összefüggéseket, az IKT-használati szokásokat felmérő kérdőív alapján a vizsgálati mintát három csoportra osztottuk. A csoportokat (keveset használók, átlagos használók, sokat használók) a következőképpen hoztuk létre: a saját korcsoportban a diákokat a 25\%-os kvadránsig a keveset számítógépező, a 75\%-os kvadránstól a sokat számítógépező csoportba soroltuk. Ezeket a csoportokat az átlagos használók csoportjával (25\% és $75 \%$ közötti számítógépezés) és egymással hasonlítottuk össze, kétmintás $t$-próbák segítségével. A főbb eredményeket a 6-8. táblázatokon szemléltetjük.

6. táblázat. Az önszabályozó tanulás fejlettsége közti különbségek az IKT-használat függvényében 9-11 éves korban

\begin{tabular}{|c|c|c|c|c|c|c|c|}
\hline & IKT-használat & $\mathrm{N}$ & Átlag & Szórás & \begin{tabular}{|l|} 
Standard \\
hibaátlag
\end{tabular} & $t$-érték & $\begin{array}{r}\text { Szign. } \\
\text { szint }\end{array}$ \\
\hline \multirow{2}{*}{$\begin{array}{l}\text { A tanulás tervezé- } \\
\text { se és kontrollja }\end{array}$} & b) & 71 & & & & \multirow{2}{*}{-1.322} & \multirow{2}{*}{0.162} \\
\hline & Átlagos (26-75\%) & 136 & 26.5882 & 7.88291 & 595 & & \\
\hline \multirow{2}{*}{$\begin{array}{l}\text { Hatékony tanulá- } \\
\text { si szokások }\end{array}$} & Sokat $(76-100 \%)$ & 76 & 15.2895 & 5.66349 & 965 & \multirow{2}{*}{-3.526} & \multirow{2}{*}{0.001} \\
\hline & Átlagos (26-75\%) & 139 & 18. & 5.0 & 76 & & \\
\hline \multirow{2}{*}{$\begin{array}{l}\text { Tanulási techni- } \\
\text { kák és stratégiák }\end{array}$} & Sokat $(76-100 \%)$ & 61 & & & & \multirow{2}{*}{-2.655} & \multirow{2}{*}{0.009} \\
\hline & Átlagos (26-75\%) & 117 & 63.9 & 19. & & & \\
\hline \multirow{2}{*}{$\begin{array}{l}\text { Metakogníció és } \\
\text { reflexió }\end{array}$} & Sokat $(76-100 \%)$ & 73 & 30.8904 & 10.85710 & 1.27073 & \multirow{2}{*}{-1.812} & \multirow{2}{*}{0.072} \\
\hline & Átlagos (26-75\%) & 127 & 33.8819 & 11.88544 & 1.05466 & & \\
\hline \multirow{2}{*}{$\begin{array}{l}\text { Tanulásdiag- } \\
\text { nosztika } \\
\text { összpontszám }\end{array}$} & Sokat $(76-100 \%)$ & 51 & 124.47 & 34.08657 & 4.77307 & \multirow{2}{*}{-2.793} & \multirow{2}{*}{0.006} \\
\hline & Átlagos (26-75\%) & 94 & 141.7021 & 37.90873 & 3.90999 & & \\
\hline
\end{tabular}


A 9-11 évesek korcsoportjában csak a hatékony tanulási szokások és a tanulási technikák alkalmazása terén találtunk szignifikáns különbséget az átlagos IKThasználók javára (6. táblázat).

A felső tagozatra ez a különbség sokkal markánsabbá válik. Az átlagos és kevés IKT-használók között nincs szignifikáns különbség, de a keveset használók kicsit jobb eredményeket érnek el a kérdőívben, mint a másik két csoport. Az infokommunikációs eszközök túl gyakori használata az önszabályozó tanulás minden területén gyengébb eredményeket hoz (7. táblázat).

7. táblázat. Az önszabályozó tanulás fejlettsége közti különbségek az IKT-használat függvényében 13-15 éves korban

\begin{tabular}{|c|c|c|c|c|c|c|c|}
\hline & IKT-használat & $\mathrm{N}$ & Átlag & Szórás & $\begin{array}{l}\text { Standard } \\
\text { hibaátlag }\end{array}$ & t-érték & $\begin{array}{r}\text { Szign. } \\
\text { szint }\end{array}$ \\
\hline \multirow{2}{*}{$\begin{array}{l}\text { A tanulás tervezé- } \\
\text { se és kontrollja }\end{array}$} & Sokat $(76-100 \%)$ & 75 & 28.8533 & 7.45200 & 0.86048 & \multirow{2}{*}{-3.23} & \multirow{2}{*}{0.002} \\
\hline & Keveset $(0-25 \%)$ & 95 & 32.6842 & 7.95635 & 0.81630 & & \\
\hline \multirow{2}{*}{$\begin{array}{l}\text { Hatékony tanulá- } \\
\text { si szokások }\end{array}$} & Sokat $(76-100 \%)$ & 78 & 16.9872 & & & \multirow{2}{*}{-2.318} & \multirow{2}{*}{0.022} \\
\hline & Keveset $(0-25 \%)$ & 97 & & & & & \\
\hline \multirow{2}{*}{$\begin{array}{l}\text { Tanulási techni- } \\
\text { kák és stratégiák }\end{array}$} & Sokat $(76-100 \%)$ & 72 & 65.2083 & 15.51640 & 1.82863 & \multirow{2}{*}{-3.188} & \multirow{2}{*}{0.002} \\
\hline & Keveset $(0-25 \%)$ & 88 & 72.6477 & 14.78664 & 1.57626 & & \\
\hline \multirow{2}{*}{$\begin{array}{l}\text { Metakogníció és } \\
\text { reflexió }\end{array}$} & Sokat $(76-100 \%)$ & 77 & & 8.43873 & & \multirow{2}{*}{-3.081} & \multirow{2}{*}{0.002} \\
\hline & Keveset $(0-25 \%)$ & 91 & 39.4286 & 8.90336 & 0.9 & & \\
\hline \multirow{2}{*}{$\begin{array}{l}\text { Önszabályozó } \\
\text { tanulás } \\
\text { összpontszám }\end{array}$} & Sokat $(76-100 \%)$ & 63 & 146.5079 & 33.00238 & 4.15791 & \multirow{2}{*}{-2.902} & \multirow{2}{*}{0.004} \\
\hline & Keveset $(0-25 \%)$ & 82 & 162.4024 & 32.27615 & 3.56430 & & \\
\hline
\end{tabular}

Bár ezek a korrelációk az okság irányát nem mutatják, valószínűnek tartjuk, hogy épp az önszabályozás gyengébb volta miatt ragadnak le az eszközök mellett. Valószínű, hogy kevésbé foglalkoznak az idejük beosztásával, kevésbé monitorozzák a saját tevékenységüket, vagy kevésbé gondolkodják át a céljaikat, a hozzá vezető utat, vagy saját magukról is kevesebbet gondolkodnak. A 17-19 éves korosztályban van egy érdekes fordulat, mert itt már nem a keveset számítógépezők csoportjának a legjobbak az önszabályozó tanulás eredményeik, hanem az átlagos használóknak. Az átlagos és sokat használók között minden területen kifejezetten erős szignifikáns különbség van az átlagos használók javára (8. táblázat).

A keveset és a sokat használók közül pedig nem minden területen szignifikánsan, de a keveset használóknál jobbak a kérdőív eredményei. 
8. táblázat. Az önszabályozó tanulás fejlettsége közti különbségek az IKT-használat függvényében 17-19 éves korban

\begin{tabular}{|c|c|c|c|c|c|c|c|}
\hline & IKT-használat & $\mathrm{N}$ & Átlag & Szórás & \begin{tabular}{|l|} 
Standard \\
hibaátlag
\end{tabular} & $t$-érték & $\begin{array}{r}\text { Szign. } \\
\text { szint }\end{array}$ \\
\hline \multirow{2}{*}{$\begin{array}{l}\text { A tanulás tervezé- } \\
\text { se és kontrollja }\end{array}$} & Sokat $(76-100 \%)$ & 74 & $32 . \angle 4 J$ & 7.303 & 0.8489 & \multirow{2}{*}{-3.831} & \multirow{2}{*}{0.000} \\
\hline & Átlagos (26-75\%) & 191 & 36.073 & 7.297 & 0.528 & & \\
\hline \multirow{2}{*}{$\begin{array}{l}\text { Hatékony tanulá- } \\
\text { si szokások }\end{array}$} & Sokat $(76-100 \%)$ & 75 & 16.653 & 4.202 & 0.4852 & \multirow{2}{*}{-2.99} & \multirow{2}{*}{0.003} \\
\hline & Átlagos (26-75\%) & 197 & 18.345 & 4.086 & 0.2911 & & \\
\hline \multirow{2}{*}{$\begin{array}{l}\text { Tanulási techni- } \\
\text { kák és stratégiák }\end{array}$} & Sokat $(76-100 \%)$ & 74 & 72.148 & 13.143 & 1.527 & \multirow{2}{*}{-2.412} & \multirow{2}{*}{0.017} \\
\hline & Átlagos (26-75\%) & 186 & & & & & \\
\hline \multirow{2}{*}{$\begin{array}{l}\text { Metakogníció és } \\
\text { reflexió }\end{array}$} & Sokat $(76-100 \%)$ & 74 & 38.054 & 6.896 & 0.801 & \multirow{2}{*}{-2.994} & \multirow{2}{*}{0.003} \\
\hline & Átlagos (26-75\%) & 191 & 40.958 & 7.546 & 0.54603 & & \\
\hline \multirow{2}{*}{$\begin{array}{l}\text { Önszabályozó } \\
\text { tanulás } \\
\text { összpontszám }\end{array}$} & Sokat $(76-100 \%)$ & 67 & 157.5 & 25.411 & 3.1 & \multirow{2}{*}{-4.237} & \multirow{2}{*}{0.000} \\
\hline & Átlagos (26-75\%) & 173 & 173.185 & 26.230 & 1.994 & & \\
\hline
\end{tabular}

Az infokommunikációs eszközök használatának sajátosságai és az önszabályozó tanulás fejlettsége közötti összefüggést vizsgálva általánosságban elmondható, hogy az átlagos vagy kevés IKT-használat fejlettebb önszabályozó sajátosságokkal jár együtt. Feltételezésünk szerint az oksági viszony éppen fordított, azaz a fejlettebb önszabályozás optimalizálja az IKT-használatot is. Az oksági irányra azonban nem rendelkezünk adatokkal, így ez a terület további vizsgálat tárgya lehet.

\section{DISZKUSSZIÓ}

Keresztmetszeti feltáró kutatásunkban elsősorban az önszabályozó tanulás fejlődési sajátosságainak feltárására törekedtünk, de vizsgáltuk annak együttjárását a tanulmányi eredményességgel és az IKT-használat gyakoriságával is. A kutatás három hipotézis köré szerveződött, diszkussziónkban ezek tükrében vizsgáljuk meg az eredményeket.

Első hipotézisünkben feltételeztük, hogy korcsoportonként eltéréseket találunk a tanulás önirányításában és a tanulási technikák használatában, és az életkor előrehaladtával növekvő értékeket kapunk az önszabályozó tanulás mentén.

Ezt a hipotézist nagyrészt igazolni tudtuk. A kutatócsoport által kifejlesztett önszabályozó tanulás kérdőívében a vizsgált négy faktorból háromban szignifikáns különbségek mutatkoztak a korosztályok között, az idősebbek javára. A Tanulás tervezése és kontrollja, valamint a Metakogníció és reflexió faktorok esetében elmondható, hogy 10 és 18 éves kor között egy viszonylag egyenletes fejlődés figyelhető meg, amely kifejezettebb az általános iskola felső tagozatában. Ez az eredmény valószínủleg a gondolkodás fejlődésének sajátosságaival van összefüggésben, hiszen a fogalmi gondolkodás kialakulása is erre az életkori szakaszra tehető. Valószínűsíthető, hogy a metakogníció gyakorlása a legmagasabb gondol- 
kodásfejlettségi fokot feltételezi. A tanulási technikák és stratégiák alkalmazása terén még a felsőoktatásban is tapasztalható fejlődés. Bizonyára épp azért, mert a felsőoktatásban jobban megkövetelt már a tananyag önálló feldolgozása, ami újabb tanulási technikák elsajátítását követeli meg a hallgatóktól.

A tanulási szokásrendszerben azonban nem tapasztaltunk fejlődést. A 22 évesek szinte ugyanannyi pontot értek el, mint a 10 évesek. Tekintettel arra, hogy a kérdőív interkorrelációs elemzésében a tanulási szokások faktorában is viszonylag magas, 0,5 feletti korrelációs együtthatókat kaptunk, nem gondoljuk, hogy a kérdőív hibája lenne ez az eredmény. Inkább arra következtetünk, hogy az alsó tagozatban kialakult tanulási szokásrendszer spontán fejlődést nem mutat. A berögződött szokások pedig csak nehezen és tudatos korrekcióval módosíthatók.

Második hipotézisünkben feltételeztük, hogy az önszabályozó tanulás kérdőívének faktoraiban azon tanulók eredményei lesznek jobbak, akik magasabb tanulmányi átlaggal és magasabb kompetenciamérési eredményekkel rendelkeznek. Ezt a hipotézist is sikerült igazolni, bár alacsony korrelációs együtthatókkal, de szignifikáns együttjárást tapasztatunk az önszabályozó tanulás fejlettségi szintje és a tanulmányi eredmények, valamint a kompetenciamérési adatok között. Joggal feltételezhető, hogy az önszabályozó tanulás fejlesztése révén javíthatók lennének a tanulmányi eredmények. A tanulási hatékonyság fejlesztése terén már vannak kutatási tapasztalataink (Dávid, 2004, 2010), de további vizsgálatokra lenne szükség, nagyobb mintán is igazolni az önszabályozó tanulás fejlesztésének teljesítménynövelő hatását.

Harmadik hipotézisünkben feltételeztük, hogy az infokommunikációs technológiák (IKT) használati gyakoriságával is összefüggésbe hozható az önszabályozó tanulás fejlettsége. Feltételeztük, hogy az IKT-eszközök átlagos mértékű használata mellett a tanulás önszabályozása is magasabb szintủ lesz. Ezt a munkahipotézist is igazolták a kutatási adatok, bár az ok-okozati összefüggés nem állapítható meg.

\section{KÖVETKEZTETÉSEK}

Az általunk lebonyolított nagy elemszámú kutatás az önszabályozó tanulás fejlődésének kutatásában egy olyan kezdőpontnak tekinthető, amely további kutatásokat és szakmai tapasztalatcseréket indukál.

Az önszabályozó tanulás kérdőívében minden korcsoportnál tapasztalható alacsony értékek rámutatnak arra, hogy tanulóinknál elengedhetetlenül szükség lenne az önszabályozó tanulás fejlesztésére. Minden korosztályban, minden faktor fejlesztésére szükség van, de különösen fontos odafigyelni arra, hogy már az alsó tagozatban a hatékonynak tekinthető tanulási szokásokat gyakoroltassák be a kisdiákokkal, mert a szokásrendszer spontán módon nem változik, nem fejlődik.

Tekintettel arra, hogy a serdülőkor után nem tapasztalható spontán javulás a tanulás tervezése és kontrollja, valamint a metakogníció területén, az élethosszig tartó tanulás érdekében azonban az önszabályozó tanulás ezen faktorai elengedhetetlenek, szükség lenne a tanulási tanácsadás egyéni és csoportos formáinak elterjesztésére mind a felsőoktatási, mind a felnőttképzési intézményekben. 
További kutatást igényelne a tanulási szokásrendszer vizsgálata, és annak kidolgozása, hogy az általános iskola alsó tagozatán milyen módszerekkel alakíthatók a hatékony tanulási szokások.

A kutatásnak azon része, amely az IKT-használat gyakoriságával vetette össze az önszabályozó tanulás fejlettségét, figyelmünk előterébe hozta magának az önkontrollnak, a viselkedés (és nem csak a tanulási viselkedés) önszabályozásának kérdését. Érdemes lenne további kutatásokat végezni ezen a terülten is.

\section{KÖSZÖNETNYILVÁNÍTÁS}

A tanulmány szerzői ezúton szeretnének köszönetet mondani a kutatásban részt vevő valamennyi kollégának, az Eszterházy Károly Főiskola Tanárképzési és Tudástechnológiai Kara dolgozóinak és doktorandusz hallgatóinak. Köszönetünket fejezzük ki továbbá a kutatásban részt vevő iskolák vezetőinek és az adatfelvételében segítségünkre siető pedagógusoknak. Köszönet illeti továbbá a Klebensberg Intézményfenntartó Központ Egri Tankerületét a kutatás lebonyolításában nyújtott támogatásáért.

„A közlemény a Társadalmi Megújulás Operatív Program »Digitális átállás az oktatásban « címet viselő, 4.2.2.D-15/1/KONV-2015-0027 azonosítószámú projekt keretében készült. A projekt az Európai Unió támogatásával, és az Európai Szociális Alap társfinanszírozásával valósult meg."

\section{IRODALOM}

Artino, A. R., \& Jones, K. D. (2012). Exploring the complex relations between achievement emotions and self-regulated learning behaviors in online learning. Internet and Higher Education, 15, 170-175.

Az egész életen át tartó tanulás szakpolitikájának keretstratégiája a 2014/2020 közötti időszakra. URL:

http://www.kormany.hu/download/7/fe/20000/Eg\%C3\%A9sz\%20\%C3\%A9leten\%20\%C3 \%A1t\%20tart\%C3\%B3\%20tanul\%C3\%A1s.pdf (letöltés dátuma: 2015. december 20.)

Bacsa É. (2012). Általános iskolások önszabályozott tanulását mérő kérdőív adaptálása. Alkalmazott Pszichológia, 14(4), 53-80.

Bandura, A. (1995). Self-efficacy in Changing Societies. Cambridge: Cambridge University Press.

Boekaerts, M. (1999). Self-regulated learning: where we are today. International Journal of Educational Research, 31(6), 445-457.

Broadbent, J., \& Poon, W. L. (2015). Self-regulated learning strategies \& academic achievement in online higher education learning environments: A systematic review. Internet and Higher Education 27, 1-13.

Csíkos Cs. (2004). Metakogníció a tanításban és a tanulásban. Iskolakultúra, 14(2), 3-12. 
Csizér K. és Kormos J. (2012). A nyelvtanulási autonómia, az önszabályozó stratégiák és a motiváció kapcsolatának vizsgálata. Magyar Pedagógia, 112(1), 3-17.

D. Molnár É. (2014). Az önszabályozott tanulás pedagógiai jelentősége. In Benedek A. és Golnhofer E. (szerk.), Tanulmányok a neveléstudomány köréböl, 2013. Tanulás és környezete (pp. 29-54). Budapest: MTA Pedagógiai Tudományos Bizottság.

Dávid M. (2004). Tanulási hatékonyság fejlesztése a felsőoktatásban csoportos tanácsadás módszerével. PhD-értekezés, Debreceni Egyetem Pszichológiai Intézete.

Dávid M. (2010). Tanulási tanácsadás a felsőoktatásban - egy empirikus kutatás eredményei. In Puskás-Vajda Zs. és Lisznyai S. (szerk.), Életszakaszok határán. Közösségi és egyéni tanulási feladatok (pp. 99-120). FETA Könyvek 5. Budapest: Felsőoktatási Tanácsadás Egyesület.

Dávid M., Estefánné Varga M. és Héjja-Nagy K. (2008). Tanulásdiagnosztikai Kérdőív bemutatása. In Perjés I. és Ollé J. (szerk.), Hatékony tudomány, pedagógiai kultúra, sikeres iskola. VIII. Országos Neveléstudományi Konferencia: Program és összefoglalók (p. 247). Budapest: MTA Pedagógiai Bizottság.

Dávid M., Taskó T. A., Héjja-Nagy K., Mester D., Dorner L., Kovács K. és Faragó B. (2015). A tanulási eredményesség összefüggései az önszabályozó tanulás, és a munkamemória fejlettségével, az IKT-használat gyakorisága függvényében. Kutatási zárótanulmány. Eger: Eszterházy Károly Főiskola.

Faragó B. (2015). Tanuláselmélet, tanulásmódszertan. In Ollé J., Kocsis Á., Molnár E., Sablik H., Pápai A. és Faragó B. (szerk.), Oktatástervezés, digitális tartalomfejlesztés (pp. 1526). Eger: Líceum Kiadó.

Fisher, R. (2000). Hogyan tanítsuk gyermekeinket tanulni. Budapest: Műszaki Könyvkiadó.

Hunya M. (2014). Reflektív pedagógus - reflektív gyakorlat. Budapest: Oktatáskutató és Fejlesztő Intézet. URL:

http://www.ofi.hu/publikacio/reflektiv-pedagogus-reflektiv-gyakorlat (A letöltés dátuma: 2015. december 15.)

Kovács Zs. (2013). Önszabályozó tanulás - értelmezési módok a kutatási metodológiák tükrében. Neveléstudomány, 1(1), 124-136.

http://nevelestudomany.elte.hu/downloads/2013/nevelestudomany_2013_1_124136.pdf (A letöltés dátuma: 2015. december 15.)

Making a European Area of Lifelong Learning a Reality. European Commission, 2001, 5.

McDermott, J. M., \& Fox, N. A. (2010). Exploring response monitoring: Individual differences and contributions to self-regulation. In R. H. Hoyle (Ed.), Handbook of Personality and Self-regulation (pp. 91-113). Chichester, UK: Wiley-Blackwell.

Molnár É. (2002). Az önszabályozó tanulás. Iskolakultúra, 9, 3-17.

Molnár É. (2009). Az önszabályozás értelmezései és elméleti megközelítései. Magyar Pedagógia, 109(4), 343-354.

Molnár Gy. (2011). Az információs-kommunikációs technológiák hatása a tanulásra és oktatásra. Magyar Tudomány, 9, 1038-1047.

Oktatási adatok 2014/15, Központi Statisztikai Hivatal. Statisztikai Tükör, (31), 2015. április 29. URL: https://www.ksh.hu/docs/hun/xftp/idoszaki/oktat/oktatas1415.pdf

Pintrich, P. R. (2000). The role of goal orientation in self-regulated learning. In M. Boekaerts, P. R. Pintrich, \& M. Zeidner (Eds), Handbook of self-regulation (pp. 452-503). San Diego, CA: Academic Press. 
Réthy E. (2003). Motiváció, tanulás, tanítás. Miért tanulunk jól vagy rosszul? Budapest: Nemzeti Tankönyvkiadó.

Revákné Markóczi I., Máth J., Huszti A. és Pollner K. (2013). A természettudományos problémamegoldás metakogníciójának mérése a felsőoktatásban. Magyar Pedagógia, 113(4), 221-241.

Rosenbaum, M. (1988). Learned resourcefulness, stress and self-regulation. In S. Fisher, \& J. Reason (Eds.), Handbook of life stress, cognition and health (pp. 483-496). Oxford, UK: John Wiley \& Sons.

Schraw, G. (2001). Promoting general metacognitive awareness. In H. J. Hartman (Ed.), Metacognition in learning and instruction: Theory, research and practice (pp. 3-16). London: Kluwer.

Semmelweis figyelő: Fiúk vagy lányok születnek többen? URL:

http://semmelweisfigyelo.hu/hu/osszes_kiemelt_cikk/hir/3930_fiuk_vagy_lanyok_szuletn ek_tobben (letöltés dátuma: 2015. december 20.)

Shih, K.-P., Chen, H.-C., Chang, C.-Y., \& Kao, T.-C. (2010). The Development and Implementation of Scaffolding-Based SelfRegulated Learning System for e/m-Learning. Educational Technology \& Society, 13(1), 80-93.

Snow, R. E. és Jackson, D. N. (1999). Az akarat egyéni különbségei: válogatott konstruktumok és mérőeszközök. In H. F. O’Neill, \& M. Drillings (szerk.), Motiváció. Elmélet és kutatás (pp. 83-112). Budapest: Vince Kiadó.

Szivák J. (2010). A reflektív gondolkodás fejlesztése. Budapest: Magyar Tehetségsegítő Szervezetek Szövetsége.

Taskó T. A. (2011). A tanulás tanitásának elmélete és gyakorlata különös tekintettel a természettudományok oktatására. Eger: EKF Líceum Kiadó.

Vermunt, J. D. (1998). The regulation of constructive learning processes. British Journal of Educational Psychology, 68(2), 149-171.

http://bit.ly/1alMZrA (Hozzáférés ideje: 2013. június 23.)

Zimmerman, B. J. (2002). Becoming a self-regulated learner: An overview. Theory into practice, 41(2), 64-70.

\title{
CONNECTION BETWEEN THE DEVELOPMENT OF SELF-REGULATED LEARNING AND LEARNING EFFECIENCY AND THE FREQUENCY OF ICT USE
}

\author{
DÁVID, MÁRIA - TASKÓ, TÜNDE - HÉJJA-NAGY, KATALIN - MESTER, DOLLI - \\ DORNER, LÁSZLÓ - ESTEFÁNNÉ VARGA, MAGDOLNA
}

Background and Aims: New educational challenges raised related to sufficient information searching and processing becoming general by the widespread of Infocommunication Technologies (ICT) use. On the part of the student, it assumes autonomous learning, effective information processing and understanding. On the part of the teacher, the role of learning management becomes more emphasized than the role of giving knowledge (Molnár, 2011). The social demand for life-long learning can't be realized without the development of self-regulated learning skills. At the same time students' self- 
reflective and self-regulated skills are still unexploited in the process of teaching and learning (Molnár, 2002). In the study we present the results of a comparative cross-sectional research. The aim of the research is to find out connections between learning effectiveness and features of ICT-use and the development of self-regulated learning.

Methods and Sample: In the cross-sectional research in the age group 10-14-18 and 22 of students completed in November 2015, we studied the development of self-regulated learning, the sample consisted of 1257 students. We used the self-regulated learning questionnaire consisting 59 items, and worked out by the research group and we assembled school records and the data of mathematical and reading comprehension competency measurement.

Results: We found significant differences between the age groups referring to the development of self-regulated learning. The results are improving in older age groups, but we got low average in almost all age groups considering the factors of the questionnaire. The level of development of selfregulated learning indicates moderate but positive significant correlation with school records and the results of competence measurements. The higher frequency of ICT use than normal ICT use indicates the lower level of self-regulated learning.

Conclusions: To develop the self-regulated learning is necessary in every age groups. It is important to pursue the ICT use do not exceed normal rate.

Key words: $\quad$ self-regulated learning, learning efficiency, ICT use 